University of Nebraska - Lincoln

DigitalCommons@University of Nebraska - Lincoln

Faculty Publications: Department of Entomology

Entomology, Department of

$10-8-2010$

\title{
Areawide Suppression of European Corn Borer with Bt Maize Reaps Savings to Non-Bt Maize Growers
}

\author{
W. D. Hutchinson \\ University of Minnesota -Twin Cities, hutch002@umn.edu \\ E. C. Burkness \\ University of Minnesota - Twin Cities \\ P. D. Mitchell \\ University of Wisconsin - Madison \\ R. D. Moon \\ University of Minnesota \\ T. W. Leslie \\ Long Island University \\ See next page for additional authors
}

Follow this and additional works at: https://digitalcommons.unl.edu/entomologyfacpub

Part of the Entomology Commons

Hutchinson, W. D.; Burkness, E. C.; Mitchell, P. D.; Moon, R. D.; Leslie, T. W.; Fleischer, S. J.; Abrahamson, M.; Hamilton, K. L.; Steffey, K. L.; Gray, M. E.; Hellmich, R. L.; Kaster, L. V.; Hunt, Thomas E.; Wright, Robert J.; Pecinovsky, K.; Rabaey, T. L.; Flood, B. R.; and Raun, E. S., "Areawide Suppression of European Corn Borer with Bt Maize Reaps Savings to Non-Bt Maize Growers" (2010). Faculty Publications: Department of Entomology. 218.

https://digitalcommons.unl.edu/entomologyfacpub/218

This Article is brought to you for free and open access by the Entomology, Department of at DigitalCommons@University of Nebraska - Lincoln. It has been accepted for inclusion in Faculty Publications: Department of Entomology by an authorized administrator of DigitalCommons@University of Nebraska - Lincoln. 


\section{Authors}

W. D. Hutchinson, E. C. Burkness, P. D. Mitchell, R. D. Moon, T. W. Leslie, S. J. Fleischer, M. Abrahamson, K. L. Hamilton, K. L. Steffey, M. E. Gray, R. L. Hellmich, L. V. Kaster, Thomas E. Hunt, Robert J. Wright, K. Pecinovsky, T. L. Rabaey, B. R. Flood, and E. S. Raun 
This article is a U.S. government work, and is not subject to copyright in the United States.

\section{Areawide Suppression of European Corn Borer with Bt Maize Reaps Savings to Non-Bt Maize Growers}

W. D. Hutchison, ${ }^{1 *}$ E. C. Burkness, ${ }^{1}$ P. D. Mitchell, ${ }^{2}$ R. D. Moon ${ }^{1}{ }^{1}$ T. W. Leslie, ${ }^{3}$ S. J. Fleischer, ${ }^{4}$ M. Abrahamson, ${ }^{5}$ K. L. Hamilton, ${ }^{6}$ K. L. Steffey, ${ }^{7} \dagger$ M. E. Gray, ${ }^{7}$ R. L. Hellmich, ${ }^{8}$ L. V. Kaster, ${ }^{9}$ T. E. Hunt, ${ }^{10}$ R. J. Wright, ${ }^{11}$ K. Pecinovsky, ${ }^{12}$ T. L. Rabaey, ${ }^{13}$ B. R. Flood, ${ }^{14}$ E. S. Raun ${ }^{15} \ddagger$

Transgenic maize engineered to express insecticidal proteins from the bacterium Bacillus thuringiensis (Bt) has become widely adopted in U.S. agriculture. In 2009, Bt maize was planted on more than 22.2 million hectares, constituting $63 \%$ of the U.S. crop. Using statistical analysis of per capita growth rate estimates, we found that areawide suppression of the primary pest Ostrinia nubilalis (European corn borer) is associated with Bt maize use. Cumulative benefits over 14 years are an estimated $\$ 3.2$ billion for maize growers in Illinois, Minnesota, and Wisconsin, with more than \$2.4 billion of this total accruing to non-Bt maize growers. Comparable estimates for lowa and Nebraska are $\$ 3.6$ billion in total, with $\$ 1.9$ billion for non-Bt maize growers. These results affirm theoretical predictions of pest population suppression and highlight economic incentives for growers to maintain non-Bt maize refugia for sustainable insect resistance management.

$\mathrm{D}$ uring the past decade, adoption of transgenic crop technology increased worldwide to reach 134 million ha of transgenic crops planted in 25 countries during 2009 (1). In the United States, maize has been the most abundant transgenic crop planted to resist insect pests, with hybrids engineered to express insecticidal proteins isolated from the bacterium Bacillus thuringiensis [i.e., Bt maize $(1,2)]$. Historically, the most widespread insect pest throughout the U.S. Corn Belt has been the European corn borer,
Ostrinia nubilalis (Hübner). The pest was accidentally introduced in the eastern United States in 1917 and subsequently spread with devastating results; losses are estimated at $\$ 1$ billion per year (3). Given the broad host range of $O$. nubilalis, the potential for Bt maize to suppress populations regionally was unclear. Furthermore, the economic impacts of such suppression had not been considered.

In 2009, plantings of Bt maize (with traits specific to preventing damage by lepidopteran pests) reached 22.2 million ha, and for the first time exceeded $63 \%$ of the total area planted with maize in the United States (4). Most of the Bt maize is distributed throughout the Midwestern U.S. Corn Belt (4) (Fig. 1). Although "stacked" $\mathrm{Bt}$ events (maize varieties expressing multiple $\mathrm{Bt}$ toxins) directed at preventing herbivory from multiple insect pests are available $(1,4)$, nearly all Bt maize hybrids sold in the United States express toxins that control $O$. nubilalis $(2,4,5)$. Because of Bt maize's high efficacy (6), there is concern that insects will evolve resistance to $\mathrm{Bt}$

${ }^{1}$ Department of Entomology, University of Minnesota, St. Paul, MN 55108, USA. ${ }^{2}$ Department of Agricultural and Applied Economics, University of Wisconsin, Madison, WI 53706, USA. ${ }^{3}$ Department of Biology, Long Island University, Brooklyn, NY 11201, USA. ${ }^{4}$ Department of Entomology, Pennsylvania State University, State College, PA 16802, USA. ${ }^{5}$ Minnesota Department of Agriculture, St. Paul, MN 55107, USA. ${ }^{6}$ Wisconsin Department of Agriculture, Trade and Consumer Protection, Madison, WI 53718, USA. ${ }^{7}$ Department of Crop Sciences, University of Illinois, Urbana, IL 61801, USA. ${ }^{8}$ USDA-ARS, Corn Insects and Crop Genetics Research Unit, Genetics Laboratory, Ames, IA 50011, USA. ' $5 y n g e n t a$ Seeds Inc., Slater, IA 50244, USA. ${ }^{10}$ Department of Entomology, University of Nebraska, NEREC, Haskell Agricultural Laboratory, Concord, NE 68728, USA. ${ }^{11}$ Department of Entomology, University of Nebraska, Lincoln, NE 68583, USA. ${ }^{12}$ lowa State University, Nashua, IA 50658, USA. ${ }^{13}$ General Mills Inc., Le Sueur, MN 56058, USA. ${ }^{14}$ Del Monte Foods, Rochelle, IL 61068, USA. ${ }^{15}$ Pest Management Co., Lincoln, NE 68506, USA.

${ }^{*}$ To whom correspondence should be addressed. E-mail: hutch002@umn.edu

†Present address: Dow AgroSciences, Indianapolis, IN 46268, USA.

‡Deceased. 
toxins $(5,7,8)$. To delay evolution of resistance, the U.S. Environmental Protection Agency (EPA) mandated that a minimum 20 to $50 \%$ of total onfarm maize be planted as non-Bt maize within $0.8 \mathrm{~km}$ of Bt fields as a structured refuge for susceptible $O$. nubilalis. Use of non-Bt maize refugia is an important element of long-term insect resistance management ( 9 ).

Some maize producers have been skeptical of allowing $O$. nubilalis damage in non-Bt maize refugia $(10,11)$. However, modeling $(7,12)$ provided a theoretical rationale for how local suppression of $O$. nubilalis could occur. Suppression was supported by the hypothesis that preferential moth oviposition in early-planted Bt maize fields (7) would reduce larval damage in nearby lateplanted non-Bt maize. More generally, for Bt and non-Bt maize fields with similar planting dates, $O$. nubilalis females are not able to distinguish between $\mathrm{Bt}$ and non-Bt maize for oviposition (13). Thus, with high larval mortality, Bt maize fields become an effective "dead-end" trap crop for $O$. nubilalis originating elsewhere (14). Although the models were theoretically appealing, it was not possible during early $\mathrm{Bt}$ maize commercialization to verify the magnitude of pest population suppression. Adult $O$. nubilalis are known to readily disperse among farms at distances of at least $800 \mathrm{~m}$ throughout their lifetime (15). Also, although maize is a major host, this pest colonizes $>200$ host plants including green beans, potato, and numerous weed species common to the Midwest region (3).

Surveys of $O$. nubilalis populations have extended from the initial documented invasion of the pest into the midwestern United States in the 1940s through the commercial adoption of $\mathrm{Bt}$ maize during the period 1996 to 2009. Surveys have included statewide annual fall surveys (16) for diapausing larvae in Minnesota, Illinois, and Wisconsin, and less extensive summer trapping for adult moths with light traps $(17,18)$ in Illinois, Minnesota, Nebraska, and Iowa. These states have experienced a range of $\mathrm{Bt}$ maize adoption since 1996, including high levels in Minnesota, Nebraska, and Iowa, moderate levels in Illinois, and low levels in Wisconsin (Figs. 1 and 2) (18).

Historically, larval surveys have indicated that O. nubilalis populations have been episodic, characterized by $\sim 6$ - to 8 -year periodicity indicative of density-dependent population growth $(7,12)$. Much of the population cycling has been attributed to the pathogen Nosema pyrausta $(12,19)$. However, since commercialization of Bt maize, some periodicity has persisted (Fig. 2), but larval populations have declined relative to the pre-Bt era, particularly since 2002 . These trends are evident in measures of larval abundance in non-Bt refuge fields alone, as well as in landscape-level means, for Bt- and non-Bt fields combined. Similar declines were found in measures of adult moth populations at eight locations in Minnesota, Illinois, Iowa, and Nebraska (18) (fig. S1).

To analyze the effects of $\mathrm{Bt}$ maize adoption on $O$. nubilalis populations, we estimated annual per capita growth rates (20) from fall larval surveys in non-Bt fields and analyzed them in relation to concurrent proportions of maize planted with Bt maize. Estimation also included antecedent larval densities in non-Bt fields, because $O$. nubilalis larval mortality increases with larval density $(7,12)$ and population growth more generally depends inversely on density (21). Analy-

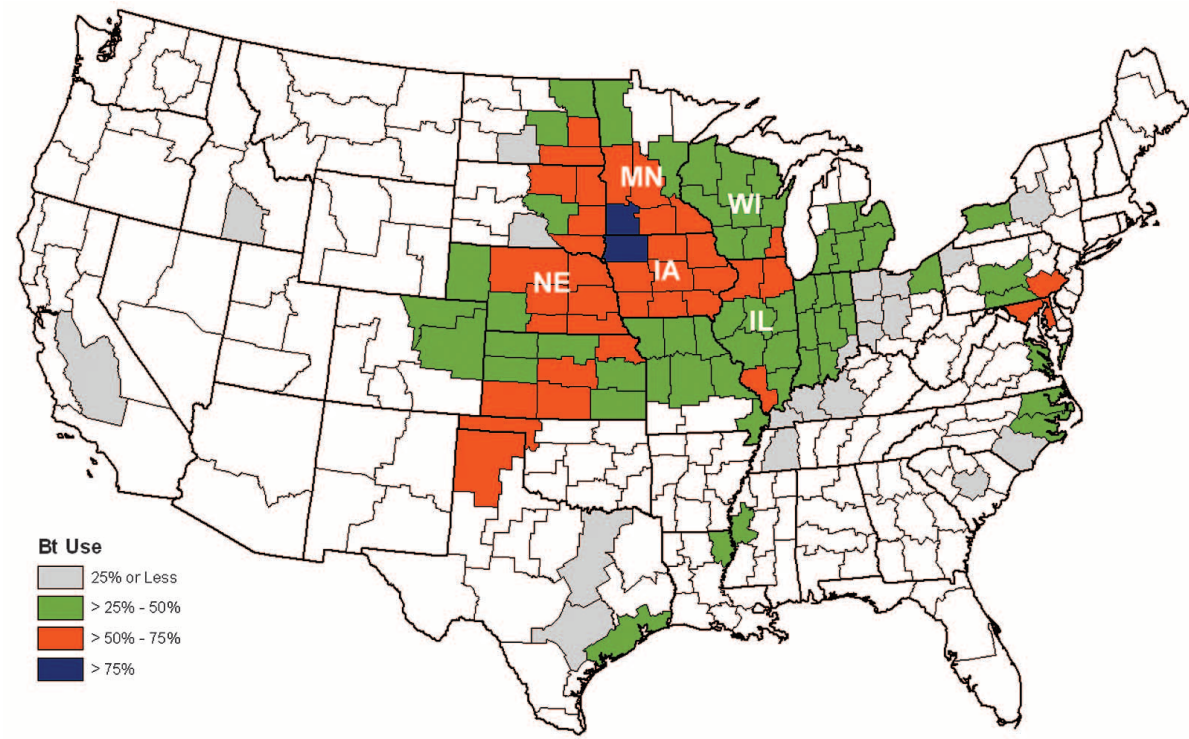

Fig. 1. Spatial distribution of maize containing one or more Bt traits for 0 . nubilalis control in 2006 in the United States. Bt maize data are from USDA crop reporting districts reporting $>40,470$ ha of maize, including the five states represented in this analysis (IL, Illinois; MN, Minnesota; WI, Wisconsin; IA, lowa; $\mathrm{NE}$, Nebraska). Areas in white had negligible maize hectares. Data are based on addresses of customer or retail outlet seed sales accounts, which may not accurately indicate cropping districts in which seed was ultimately planted. [@2008 Agricultural Biotechnology Stewardship Technical Committee]

sis used least-squares regression of growth rates in natural logarithm scale with three main effects: a state indicator variable to capture historical differences in mean densities among the three states, the natural logarithm of the antecedent larval density, and the proportion of Bt maize. Relative support for different models was evaluated with multimodel inference, with support weights based on the Bayesian information criterion, which balances reductions in residual sums of squares with numbers of parameters estimated $(18,22)$.

Relative support was greatest $(82 \%)$ for the hypothesis that per capita growth rates differed among the three states, were inversely related to larval density, and were also inversely related to level of Bt maize adoption in each state (Table 1 and Fig. 3). The model with greatest support accounted for $38 \%$ of the variation in growth rates in non-Bt fields over all states and years combined. Models with just one or two of the three main effects and with interactions among the main effects had weak support (18) (table S2).

We used the fitted regression models to estimate mean densities for populations before and after adoption of Bt maize in each state (Table 1). Before Bt maize was adopted, the density in Minnesota was 59 larvae per 100 plants; from 1996 onward, when
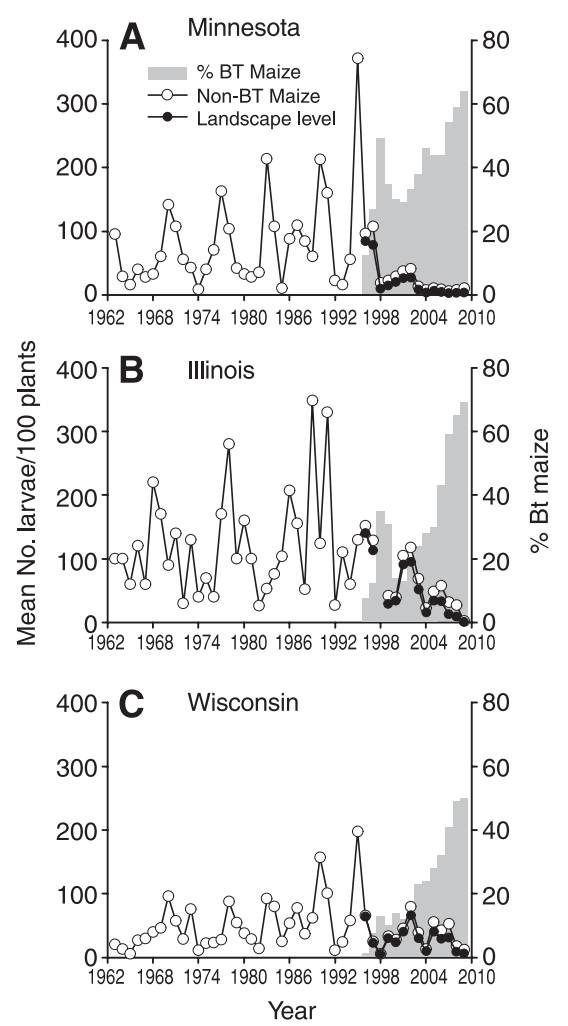

Fig. 2. Statewide average numbers of $O$. nubilalis larvae per 100 plants over the period 1963 to 2009 in (A) Minnesota, (B) Illinois, and (C) Wisconsin. Minnesota data were adjusted to landscape means (Bt and non-Bt maize fields) for comparisons with Illinois and Wisconsin landscape means, based on proportion of non-Bt corn hectares (18). Illinois and Wisconsin landscape means were adjusted for nonBt maize hectares planted in each state (18). 
Table 1. Regression statistics and estimated mean densities of $O$. nubilalis larvae per 100 plants before adoption of Bt maize in three midwestern states, and in non-Bt fields for 14 years (1996 to 2009) after adoption of Bt maize.
Coefficients for the regression model for per capita growth rate, $r=\ln \left(N_{t} / N_{t-1}\right)$, are $b_{0}$ for intercept, $b_{1}$ for regressor $D=\ln \left(N_{t-1}\right)$, and $b_{2}$ for regressor $P B t=\mathrm{Bt}$ maize proportion of crop.

\begin{tabular}{|c|c|c|c|c|c|c|c|c|c|c|c|}
\hline \multirow[b]{2}{*}{ Analysis* } & \multirow[b]{2}{*}{ State } & \multirow[b]{2}{*}{$n$} & \multirow[b]{2}{*}{$R^{2}$} & \multicolumn{3}{|c|}{ Model coefficients } & \multicolumn{2}{|c|}{ Pre-Bt density† } & \multirow{2}{*}{$\begin{array}{c}\text { Avg. } \\
\text { PBt }\end{array}$} & \multicolumn{2}{|c|}{ Bt-era density } \\
\hline & & & & $b_{0}( \pm \mathrm{SE})$ & $b_{1}( \pm \mathrm{SE})$ & $b_{2}( \pm \mathrm{SE})$ & Mean & $\mathrm{Cl}$ & & Mean & $\mathrm{Cl}$ \\
\hline \multirow{3}{*}{ By state } & Minnesota & 46 & 0.35 & $2.75(0.56)$ & $-0.67(0.13)$ & $-2.20(0.67)$ & 59 & $40-88$ & 0.40 & 16 & $9-29$ \\
\hline & Illinois & 64 & 0.44 & $4.35(0.64)$ & $-0.93(0.14)$ & $-2.98(0.60)$ & 105 & $87-128$ & 0.32 & 38 & $26-56$ \\
\hline & Wisconsin & 67 & 0.37 & $2.82(0.45)$ & $-0.76(0.12)$ & $-1.10(0.76)$ & 40 & $31-51$ & 0.23 & 29 & $19-44$ \\
\hline \multirow[t]{3}{*}{ Combined } & Minnesota & - & - & $3.07(0.15)$ & - & - & 57 & $44-75$ & 0.40 & 18 & $11-27$ \\
\hline & Illinois & 177 & 0.38 & $3.51(0.35)$ & $-0.76(0.07)$ & $-2.23(0.37)$ & 103 & 80-131 & 0.32 & 40 & $28-57$ \\
\hline & Wisconsin & - & - & $2.85(0.14)$ & - & - & 43 & $32-58$ & 0.23 & 22 & $15-31$ \\
\hline
\end{tabular}

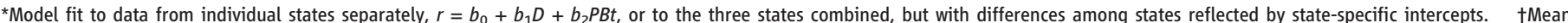

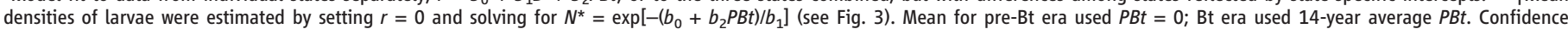
intervals $(95 \% \mathrm{Cls})$ were estimated with the delta method $(18)$ in log scale and then back-transformed to arithmetic scale.

A

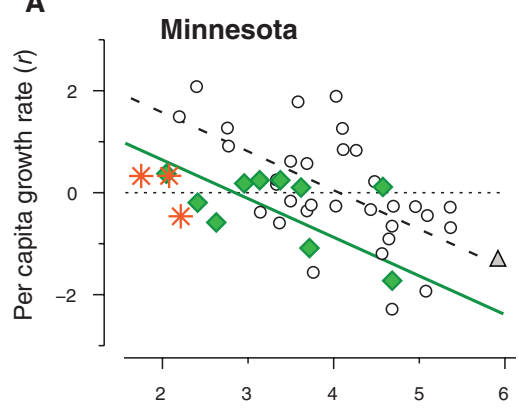

B

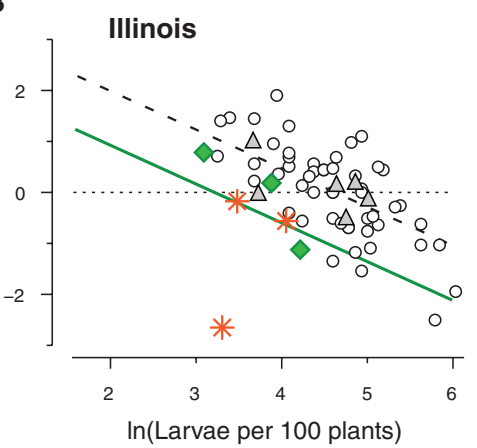

C

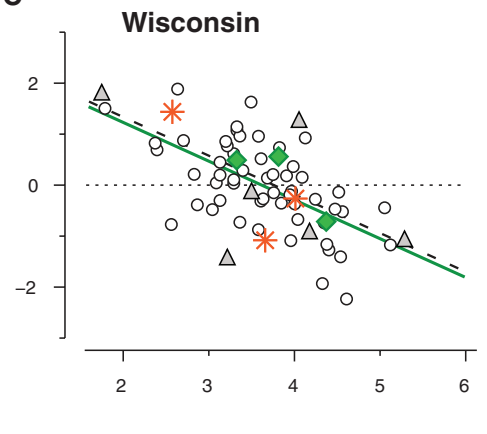

Fig. 3. Effects of Bt maize adoption on relation between larval density and annual per capita growth rates of $O$. nubilalis larval populations in non-Bt maize in three U.S. states: (A) Minnesota, (B) Illinois, (C) Wisconsin. Symbols indicate level of Bt maize adoption: open circles, pre-Bt years; gray triangles, 1 to $25 \%$; green diamonds, 26 to $50 \%$; orange asterisks, $>51 \%$. Bold dashed black line is least- squares fit for main-effects model, states combined, with $P B t=0$; green line is same with PBt equal to respective statewide 14-year average (Table 1 ). Intersections between dotted lines at $r=0$ and bold dashed lines indicate estimated mean density before adoption of Bt maize, and intersections with green solid lines show extent to which density declined with adoption of Bt maize in each state (Table 1). the proportion of maize planted to Bt averaged 0.40 (i.e., $40 \%$ adoption), mean density declined by $\sim 73 \%$ to $\sim 16$ larvae per 100 plants. In Illinois and Wisconsin, where respective average $\mathrm{Bt}$ adoption levels were $32 \%$ and $23 \%$, mean densities were reduced by $\sim 64 \%$ and $\sim 27 \%$, respectively. Similar reductions in estimated mean densities were observed when data from all three states were analyzed together (Table 1) and when landscape-level means from $\mathrm{Bt}$ fields and non-Bt fields were analyzed (18) (table S3 and fig. S2). Although many factors are known to affect $O$. nubilalis population dynamics, including weather and natural enemies $(3,12,16,19)$, these results indicate that reductions in $O$. nubilalis were associated with commercialization of $\mathrm{Bt}$ maize.

Of the five states analyzed, Iowa, Illinois, Nebraska, and Minnesota are the top four maizeproducing states in the United States, with yields in 2009 valued at \$27.1 billion (18) (tables S1 and S4). Combining analysis of the larval and moth data with annual USDA data for maize yield, price, and planted area, we estimated the annual benefits from 1996 to 2009 for both Bt- and non-Bt maize growers in each state (18). Direct benefits for Bt maize growers were calculated as the value of the yield gain for $\mathrm{Bt}$ maize relative to non-Bt maize, minus the additional cost for Bt maize seed (18) (tables S4 and S5). Suppression benefits for non-Bt maize growers were calculated as the value of avoided yield losses under the assumption that the $O$. nubilalis populations in each state would have remained at their respective historical averages if $\mathrm{Bt}$ maize had not been commercialized. What actual $O$. nubilalis populations would have actually been without commercialization of $\mathrm{Bt}$ maize cannot be determined. However, midwestern farmers expected continual problems, as $67 \%$ of midwestern farmers reported in 1997 that $O$. nubilalis was a consistent problem in their fields (10). Mean yield losses for our analysis were calculated on the basis of $O$. nubilalis population densities and estimated models of larval stalk tunneling and associated yield loss $(23,24)$. Calculations used observed statewide survey densities for Illinois, Minnesota, and Wisconsin. For Iowa and Nebraska, observed average larval densities collected at research plots at locations around the state were used when available $(1997,2000$, 2001, and 2002); otherwise, larval densities were estimated from historical averages at a few locations and the observed proportional larval decline in Minnesota, a state with Bt maize adoption rates similar to Iowa and Nebraska (18) (Fig. 1, table S1, and supplemental documentation file). Given the different nature of these larval data, loss estimates for Iowa and Nebraska are reported separately.

On the basis of these calculations, we estimate that cumulative benefits for both $\mathrm{Bt}$ and non- $\mathrm{Bt}$ maize growers during the past 14 years were almost $\$ 6.9$ billion in the five-state region (18.7 million ha in 2009) - more than $\$ 3.2$ billion in Illinois, Minnesota, and Wisconsin, and \$3.6 billion in Iowa and Nebraska (Fig. 4). Of this $\$ 6.9$ billion total, cumulative suppression benefits to non-Bt maize growers resulting from $O$. nubilalis population suppression in non-Bt maize exceeded $\$ 4.3$ billion-more than \$2.4 billion in Illinois, Minnesota, and Wisconsin, and $\$ 1.9$ billion in Iowa and Nebraska - or about $63 \%$ of the total benefits. Direct benefits for Bt maize growers (Fig. 4, A and B) were reduced because of the additional cost for Bt seed over the 14 growing seasons, which we estimate to have a cumulative value of almost $\$ 1.7$ billion, whereas non-Bt maize experienced lower $O$. nubilalis damage as a result of areawide suppression at no additional cost.

In Illinois, Minnesota, and Wisconsin, suppression benefits for non-Bt maize growers (Fig. 4C) were initially larger (albeit dominated by Illinois and Minnesota) but more quickly exceeded the direct benefits for $\mathrm{Bt}$ maize, because population suppression occurred more rapidly than in Iowa and Nebraska (Fig. 4D). In Iowa and Nebraska, total grower benefits were larger because initial long-term population densities were greater. From 2007 onward, cumulative benefits for non-Bt maize growers exceeded benefits for Bt maize growers because suppression had become more effective. 

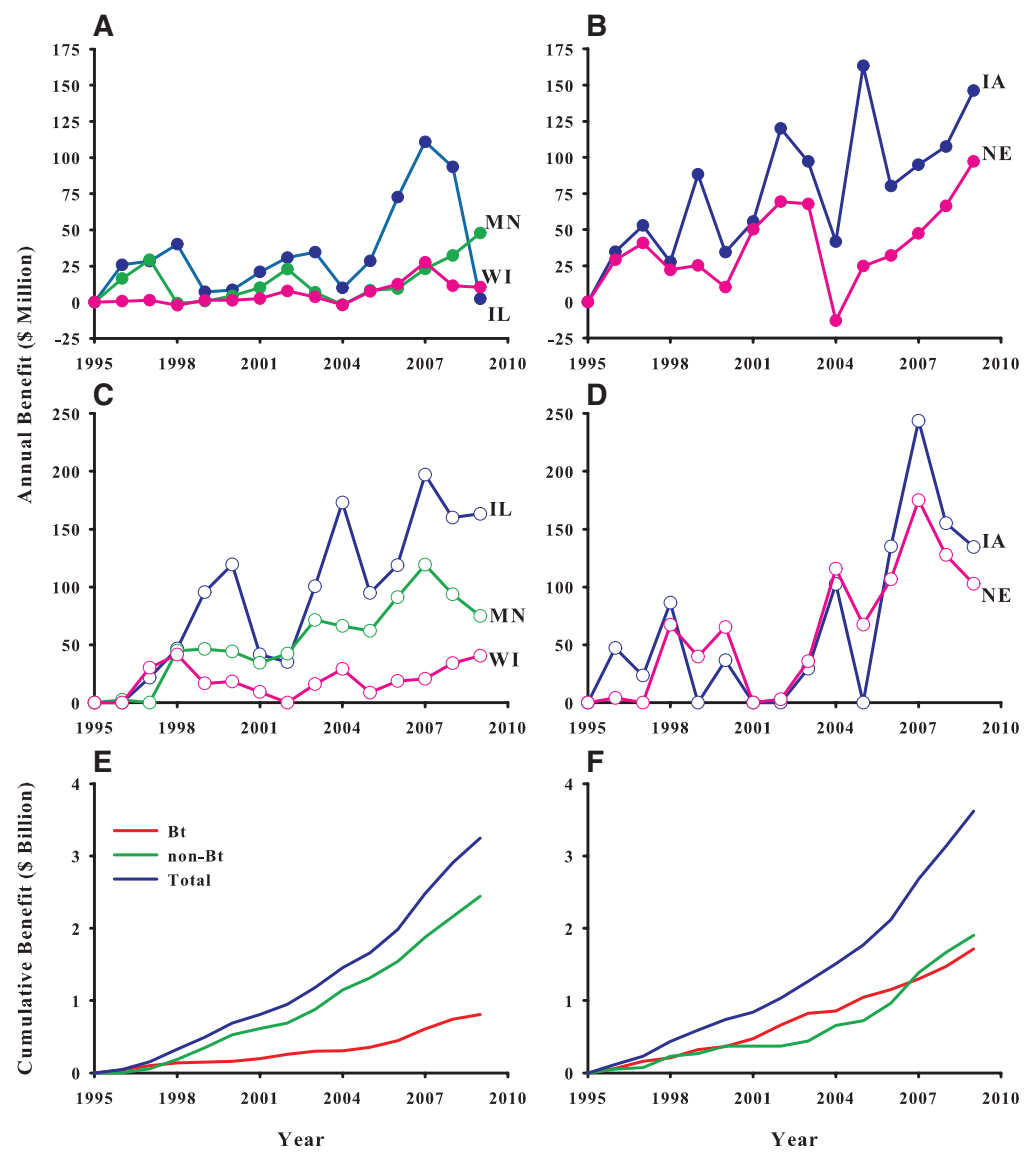

Fig. 4. (A and B) Annual benefits for Bt maize hectares, by state. (C and $\mathbf{D})$ Annual pest suppression benefits for non-Bt hectares, by state. (E and F) Cumulative benefits across states. Benefits are expressed in 2009 dollars.

These benefit estimates do not incorporate effects of price changes and shifts in planted area that would have resulted without commercialization of $\mathrm{Bt}$ maize. Nevertheless, the calculations serve to indicate the potential magnitude of maize supply increase, and its market value resulting from areawide suppression of $O$. nubilalis in these five states.

Regional reductions in the pink bollworm (Pectinophora gossypiella), which is fairly specialized to cotton (near-monophagous), have been reported from the use of Bt cotton in the United States (25). Also, areawide suppression of the polyphagous lepidopteran pest Helicoverpa armigera by Bt cotton in China has been reported (26). Reductions in $O$. nubilalis populations related to $\mathrm{Bt}$ maize have also been reported in other parts of the United States (27). We show here that pest suppression is directly associated with the use of transgenic maize. In addition, our findings indicate that economic benefits accrue not only to farmers planting Bt maize, but also to those planting non-Bt maize as a result of areawide pest suppression, and that these suppression benefits can equal or exceed the benefits to Bt maize growers.

These results highlight the need to account for economic benefits of pest suppression for non- $\mathrm{Bt}$ maize, as well as for direct economic benefits of $\mathrm{Bt}$ maize (28). Moreover, as $O$. nubilalis is highly poly- phagous, the observed regional population declines suggest that traditional and organic farmers growing other crops might also benefit (29). Sustained economic and environmental benefits of this technology, however, will depend on continued stewardship by producers to maintain non-Bt maize refugia $(5,7-10)$ to minimize the risk of evolution of $\mathrm{Bt}$ resistance in crop pest species, and also on the dynamics of Bt resistance evolution at low pest densities and for variable pest phenotypes $(30,31)$.

\section{References and Notes}

1. C. James, Global Status of Commercialized Biotech/GM Crops: 2009 (ISAAA Briefs No. 41, International Service for the Acquisition of Agri-Biotech Applications, Ithaca, NY, 2009)

2. K. R. Ostlie, W. D. Hutchison, R. L. Hellmich Eds., Bt Corn and European Corn Borer: Long-Term Success Through Resistance Management (NCR-602, University of Minnesota, St. Paul, MN, 1997).

3. C. E. Mason et al., European Corn Borer Ecology and Management (NCR-327, lowa State University, Ames, IA, 1996).

4. USDA-ERS, Adoption of Genetically Engineered Crops in the U.S.: Corn Varieties (www.ers.usda.gov/data/ BiotechCrops/ExtentofAdoptionTable1.htm).

5. B. E. Tabashnik, Proc. Natl. Acad. Sci. U.S.A. 105, 19029 (2008).

6. E. C. Burkness et al., Crop Prot. 21, 157 (2002).

7. D. N. Alstad, D. A. Andow, Science 268, 1894 (1995).

8. E. J. G. Pereira, N. P. Storer, B. D. Siegfried, Bull. Entomol. Res. 98, 621 (2008).
9. P. Lewis et al., Bt Plant-Pesticides Risk and Benefit Assessments (SAP Report No. 2000-07a, U.S. Environmental Protection Agency, 12 March 2001), pp. 5-33.

10. C. D. Pilcher et al., J. Econ. Entomol. 95, 878 (2002).

11. ]. Goldberger, J. Merrill, T. M. Hurley, AgBioForum 8, 151 (2005).

12. D. W. Onstad, C. A. Guse, J. Econ. Entomol. 92, 1256 (1999).

13. R. L. Hellmich, L. S. Higgins, J. F. Witkowski, J. E. Campbell, L. C. Lewis, J. Econ. Entomol. 92, 1014 (1999).

14. A. M. Shelton, F. R. Badenes-Perez, Annu. Rev. Entomol. 51, 285 (2006)

15. B. J. Reardon, D. V. Sumerford, T. W. Sappington, J. Econ. Entomol. 99, 1641 (2006).

16. R. E. Hill, W. J. Gary, Environ. Entomol. 8, 91 (1979).

17. D. W. Bartels, W. D. Hutchison, S. Udayagiri, J. Econ. Entomol. 90, 449 (1997).

18. See supporting material on Science Online.

19. L. C. Lewis, D. J. Bruck, ]. R. Prasifka, E. S. Raun, Biol. Control 48, 223 (2009).

20. T. Royama, Analytical Population Dynamics (Chapman \& Hall, London, 1992).

21. R. M. Sibly, D. Barker, M. C. Denham, ]. Hone, M. Pagel, Science 309, 607 (2005).

22. K. P. Burnham, D. R. Anderson, Model Selection and Multimodel Inference: A Practical Information-Theoretic Approach (Springer, New York, ed. 2, 2002).

23. P. D. Mitchell, T. M. Hurley, B. A. Babcock, R. L. Hellmich, J. Agric. Resource Econ. 27, 390 (2002).

24. T. M. Hurley, P. D. Mitchell, M. E. Rice, Am. J. Agric. Econ. 86, 345 (2004)

25. Y. Carrière et al., Proc. Natl. Acad. Sci. U.S.A. 100 1519 (2003)

26. K.-M. Wu, Y.-H. Lu, H.-Q. Feng, Y.-Y. Jiang, ].-Z. Zhao, Science 321, 1676 (2008).

27. N. P. Storer, G. P. Dively, R. A. Herman, in Integration of Insect-Resistant Genetically Modified Crops Within IPM Programs, ]. Romeis et al., Eds. (Springer, London, 2008), pp. 273-302.

28. G. Brookes, P. Barfoot, AgBioForum 11, 21 (2008).

29. W. Hutchison, E. Burkness, "Indirect Benefits of Bt Field Corn to Minnesota Sweet Corn Growers," Minnesota Fruit and Vegetable IPM News, 6 June 2008 (www.vegedge. umn.edu/MNFruit\&VegNews/vol5/vol5n4.htm).

30. M. S. Sisterson, L. A. Antilla, Y. Carrière, C. Ellers-Kirk, B. E. Tabashnik, J. Econ. Entomol. 97, 1413 (2004).

31. M. E. O'Rourke, T. W. Sappington, S. J. Fleischer, Ecol. Appl. 20, 1228 (2010).

32. This study is part of a large-scale monitoring program for O. nubilalis via cooperating members of USDA Multistate Project NC-205, "Ecology and Management of European Corn Borer and Other Lepidopteran Pests of Corn." Support was also provided by personnel with state departments of agriculture, agricultural experiment stations, and cooperative extension, and a grant from the Rapid Agricultural Response Fund, University of Minnesota. We acknowledge numerous growers who permitted data collection from commercial maize fields over the past 50 years. We thank ]. Dyer, L. Lewis, B. Gunnarson, and R. Ritland for technical support, and Y. Carrière, J. Chapman, J.-Z. Zhou, and J. P. Chavas for reviews of earlier versions of the manuscript. P.D.M. also provides limited private economic consulting services to agencies, universities, and private companies, which in the past 3 years has included small projects for Monsanto, Pioneer Hi-Bred International, and Syngenta on topics unrelated to this paper. Mention of a proprietary product does not constitute an endorsement or a recommendation for its use by the universities associated with this research or the USDA.

Supporting Online Material

www.sciencemag.org/cgi/content/full/330/6001/222/DC1 SOM Text

Tables S1 to S5

Figs. S1 and S2

Excel file

30 March 2010; accepted 9 August 2010

10.1126/science.1190242 


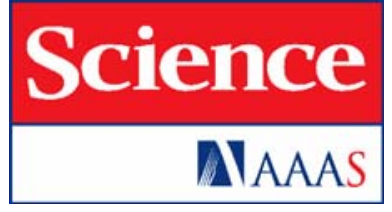

\title{
Supporting Online Material for
}

\section{Areawide Suppression of European Corn Borer with Bt Maize Reaps Savings to Non-Bt Maize Growers}

\author{
W. D. Hutchison,* E. C. Burkness, P. D. Mitchell, R. D. Moon, T. W. Leslie, S. J. Fleischer, \\ M. Abrahamson, K. L. Hamilton, K. L. Steffey, M. E. Gray, R. L. Hellmich, L. V. Kaster, \\ T. E. Hunt, R. J. Wright, K. Pecinovsky, T. L. Rabaey, B. R. Flood, E. S. Raun
}

*To whom correspondence should be addressed. E-mail: hutch002@umn.edu

Published 8 October 2010, Science 330, 222 (2010)

DOI: $10.1126 /$ science.1190242

\section{This PDF file includes:}

SOM Text

Tables S1 to S5

Figs. S1 and S2

Other Supporting Online Material for this manuscript includes the following:

Excel file (O. nubilalis larval and moth data, by year and by state) 


\section{Supporting Online Material}

\section{Demographic Analysis}

Protocols for long-term sampling of larvae and adults of European corn borer, Ostrinia nubilalis, were developed by cooperating scientists participating with the U.S. Dept. of Agric. (USDA) Multistate Project (NC-205), "Ecology and Management of European Corn Borer and Other Lepidopteran Pests of Corn," as well as state Departments of Agriculture and Cooperative Extension staff (S1-S3). Larval sampling methods for autumn infestations prior to harvest have been used in selected states in the Midwestern U.S. for over 50 years since the arrival of $O$. nubilalis (S1-S3). Black-light traps to monitor adult moth flights, based on the current trap design, have also been used for over 30 years (e.g., S4).

\section{Larval sampling}

Long-term time series of larval data for analysis were available from Minnesota (1963-2009), Illinois (1943-1996; 1999-2009) and Wisconsin (1943-2009) (Fig. 2). These states represent high, medium and low rates of Bt maize use, respectively (table S1; see also S5-S9). All statewide averages of larvae are provided in a spreadsheet (Excel) file.

Larval populations in those states were sampled routinely in autumn, during Sep.-Oct. from ca. 200-500 commercial maize fields per state (S1-S3). Sampling intensity was 10-25 randomly chosen plants per field, and chosen plants were dissected to assess larval damage and numbers of overwintering $4^{\text {th }}-5^{\text {th }}$ instar $O$. nubilalis larvae (S1-S3). Additional information regarding protocols for autumn surveys for $O$. nubilalis larval density is available at the University of Illinois (S1).

Field selection procedures differed among the three states. In Minnesota, surveyors assumed larvae would be absent in Bt maize, so they only sampled non-Bt fields from 1996 onward. Surveyors identified a sample of non-Bt fields early in each year, in cooperation with growers, and then returned in autumn to examine the pre-selected fields (M. Abrahamson, Minn. Dept. of Agric., unpublished data). This procedure provided an unbiased estimate of larval densities in non-Bt fields within the state, and we refer to such means as mean densities in non-Bt fields. In contrast, surveyors in Illinois and Wisconsin used a different approach (S1-S3), where all fieldsBt- and non-Bt combined - were sampled at random and in proportion to their availability on the landscape. In these cases, the statewide estimates of larvae per 100 plants represented a mean for both kinds of fields combined, weighted by relative abundance of the two types of maize. We refer to these measures as "landscape" means.

Given that Bt maize kills virtually $100 \%$ of O. nubilalis larvae (e.g., S10), one can convert landscape means into non-Bt means and vice versa, based on the statewide mean proportions of all maize planted in Bt varieties in a given state and year. Formally,

$$
N_{\text {non-Bt }}=N_{\text {Land }} /(1-P B t)
$$

where, $N_{\text {non-Bt }}$ is the statewide mean number of larvae per 100 plants in non-Bt fields, $N_{\text {Land }}$ is the statewide landscape mean from all fields, Bt and non-Bt maize combined, and $P B t$ is the proportion of the state's maize crop planted in Bt maize, assumed to range from 0 to $<1.0$ (S7-S8; 
table S1). To illustrate, for a landscape mean of 40 larvae per 100 plants in Illinois in 2006 and statewide $P B t$ maize $=0.43$ (table S1), the corresponding non-Bt mean would be $40 /(1-0.43)$ $=70.2$ larvae per 100 plants (e.g., Fig. 2). The reverse conversion would be $N_{\text {Land }}=N_{\text {non-Bt }}(1-$ $P B t)$. Currently, estimates of proportion of Bt maize planted in the U.S. are only available as statewide yearly averages (S8), so further analysis on a finer spatial scale is not possible.

The non-Bt maize (refuge) and landscape sampling methods yielded similar patterns of episodic dynamics in the $O$. nubilalis larval populations and a gradual reduction in larval population densities since the introduction of Bt maize in 1996 (Fig. 2, main paper). Evident was a minor peak in O. nubilalis density in 2001-2002 in all three states, and this peak was ca. 7 years after the previous peak shortly before first Bt-maize adoption in each state.

\section{Moth sampling}

Adult moth flight data were obtained from 8 locations in Minnesota, Illinois, Iowa, Nebraska, the four states with greatest Bt maize adoption. Standard black-light traps were used to collect moths (S4) at each location, and traps were checked 3-5 days per week. In most cases, trapped males and females in generations 1 and 2 of a given year were totaled, and trapping was done in years before and after Bt maize use (1990 or 1991 through 2009). Trap data from Rosemount and Blue Earth in Minnesota spanned 1991-2009; data from Le Sueur were available from 1990-1992 and 1995-2009. Data from Ames, Iowa, included only female moths in the $2^{\text {nd }}$ generation, and were available from 1990-2009, except for 1998; data from Slater included both sexes and generations, and spanned 1990-2009. Data from Clay Center, Nebraska, included 1991-2009, 1998 missing. Data from Concord, Nebraska, included the years from 1990-2009, with 2001 missing. Data from Illinois include the years from 1990-2009. These data are summarized in fig. S1. Before commercialization of $\mathrm{Bt}$ maize, trapping data at most locations involved relatively high catch rates in many years, but after commercialization, numbers of captured moths became consistently low.

\section{Regression analysis of population growth rates}

Statewide non-Bt means in Minnesota, Illinois and Wisconsin $\left(N_{t}\right)$ were used to assess population growth in relation to state of origin, larval density, and proportion Bt maize. Growth in years 2 to the end of each year's series was calculated as $r_{t}=\ln \left(N_{t} / N_{t-1}\right)$ (e.g., S11-S12). Matching explanatory variables for each year were $S_{i}$ is an indicator variable for state of origin, $D_{t-1}=\ln \left(N_{t-}\right.$ 1) is larval density in the natural logarithm scale, and $P B t$ is the estimated proportion of total maize crop in each state that was planted with Bt maize.

We considered all possible models of increasing complexity in an exploratory analysis of plausible determinants of growth rate (table S2). Simple models contained single explanatory variables $S, D$, or PBt. Alternative models contained two or more of those main effects, and possible pair-wise interactions. A "full" model contained all three main effects, all pairwise interactions, and the one 3-way interaction.

An effect of state $(S)$ would represent a variety of "nuisance' processes that could differ among states, including state-to-state differences in weather, agronomic practices, and dispersion of maize (both $\mathrm{Bt}$ and non-Bt) among other crops and non-crop habitats. An effect of density $(D)$ was expected, and would reflect density-dependent survival of pre-adult life stages, reproduction by adults, or both. An effect of Bt-maize adoption $(P B t)$ would occur if net migration by moths 
was from non-Bt source fields into neighboring Bt fields, but not the reverse. Effects of the three explanatory variables and interactions were assumed to be additive and linear in the natural logarithm scale.

Each model was fit with $1 \mathrm{~m}$ in R 2.10.1 (R Development Core Team 2009), the Bayesian information criterion statistic (BIC) was extracted with the AIC procedure (using $k=\ln [$ no. cases]). Relative support, $w_{i}$, for the $i=1 \ldots 18$ models was calculated from BIC differences $(\Delta \mathrm{BIC})$ (S13). Model adequacy was checked graphically by examining residuals for unequal variance, non-normality, and systematic curvilinearity over the range of predictor and fitted values. Conclusions were that within the range of the explanatory variables, residuals were normal; their variances were equal across predicted growth rates, densities and levels of PBt; and curvilinearity was absent.

One model with main effects of $S, D$, and $P B t$ had greatest support ( $w=0.82)$, a second model with addition of a $D$-by- $P B t$ interaction had less than a third as much support $(w=0.14)$, and the remaining 16 models had relatively little support (table S2). Superiority of the simple main effects model indicated population growth varied jointly with state of origin, density, and proportion Bt. Weakness of support for models with interactions with state indicated effects of density and proportion Bt were statistically indistinguishable among the three states (Table 1).

A parallel analysis of growth rates based on landscape mean densities in non-Bt and Bt-maize fields yielded conclusions that were equivalent to those based on refuge-level mean densities (non-Bt fields only). Support was strongest for the model with main effects of density, proportion $\mathrm{Bt}$, and state, and support was weak for all remaining models (results not shown). Estimated regression coefficients and mean densities before and after adoption of Bt maize (table S3, fig. S2) were equivalent to those estimated from larval densities in non-Bt refuge fields alone.

\section{Economic Analysis}

\section{Yield loss}

The function relating the state average fall-collected $O$. nubilalis larval population density and the expected proportion of yield loss was derived using published models (S15-16). For a given field, the average $\mathrm{cm}$ of larval tunneling per stalk has a lognormal distribution with a mean of $m=2.56 n+5.65 n^{0.5}$ and a standard deviation of $s=3.40+1.73 n$, where $n$ is the field average fallcollected $O$. nubilalis larval population density per plant (S15). For a given $\mathrm{cm}$ of stalk tunneling, the proportion of damage-free yield loss is $\lambda=0.21 T^{0.58}+0.058 \varepsilon$, where $T$ is $\mathrm{cm}$ of stalk tunneling and $\varepsilon$ is a standard normal error (S16). An explicit expression for the expected value of proportional yield loss $(\mathrm{E}[\lambda])$ as a function of the larval population density $(n)$ is possible because a lognormal random variable raised to a power is also a lognormal random variable (S17). Hence, $\mathrm{E}[\lambda]=0.021\left[\mathrm{~m}^{2} /\left(\mathrm{m}^{2}+s^{2}\right)^{0.5}\right]^{0.058}=0.021 \mathrm{~m}^{1.16} /\left(\mathrm{m}^{2}+\mathrm{s}^{2}\right)^{0.029}$, where $m$ and $s$ are the previously defined mean and standard deviation of stalk tunneling.

\section{Imputing state average $B t$ and non-Bt yields}

We use the observed state average yield, the Bt maize adoption rate, and the state average fallcollected $O$. nubilalis larval population density to impute the state average yield for $\mathrm{Bt}$ and non-Bt 
maize. The observed average state yield (table S5) is a weighted average of the average state yields for Bt and non-Bt: $Y_{s t}=\beta Y_{B t}+(1-\beta) Y_{\text {non-Bt }}$, where $Y_{s t}$ is the observed average state maize yield, $Y_{B t}$ is the average state yield for Bt maize, $Y_{\text {non-Bt }}$ is the average state yield for non-Bt maize, and $\beta$ is the proportion of the state's maize planted in Bt maize (table $\mathrm{S} 1$ ). If non-Bt yield differs from Bt yield solely due to yield loss from $O$. nubilalis damage, then $Y_{\text {non-Bt }}$ can be expressed as the following function of $Y_{B t}: Y_{n o n-B t}=(1-\mathrm{E}[\lambda]) Y_{B t}$, where $\mathrm{E}[\lambda]$ is the average proportion of yield lost from $O$. nubilalis larval damage. Substituting this expression for $Y_{\text {non-Bt }}$ into the expression for the observed average state maize yield $\left(Y_{s t}\right)$ and solving for $Y_{B t}$ gives $Y_{B t}=Y_{s t} /[1-(1-\beta) \mathrm{E}[\lambda]]$, which is the average state yield for Bt maize as a function of the observed average state maize yield $\left(Y_{s t}\right)$, the adoption rate $(\beta)$ and the average yield loss $(\mathrm{E}[\lambda])$ (table S5). Substituting this result for $Y_{B t}$ into the original expression for $Y_{\text {non-Bt }}$ then gives $Y_{n o n-B t}=(1-\mathrm{E}[\lambda]) Y_{B t}=(1-\mathrm{E}[\lambda]) Y_{s t} /(1-(1-\beta) E[\lambda])$, which is the average state yield for non-Bt maize as a function of the observed average state maize yield $\left(Y_{s t}\right)$, the adoption rate $(\beta)$ and the average yield loss $(\mathrm{E}[\lambda])$ (table S5).

\section{Larval data}

Pre-Bt average larval densities for Illinois, Minnesota, and Wisconsin were calculated as the average of the state average larval densities from the annual fall surveys for the 20 years before $\mathrm{Bt}$ maize was commercialized (1976-1995). The averages were 1.33/plant for Illinois, 1.00/plant for Minnesota, and 0.63/plant for Wisconsin (see SOM data file). Average larval densities for Iowa and Nebraska were based on historical data assembled for this analysis. The pre-Bt average was 1.80/plant for Nebraska, based on field data from Cuming and Hall counties, 1960-1969 (S15-16, S20). The pre-Bt average was 1.50/plant for Iowa, based on field data from previous reports (S20, S22-24). The spreadsheet created to document this analysis provides these larval data (see Documentation section, Excel file).

The pre-Bt averages for Illinois, Minnesota and Wisconsin are different from the mean larval densities reported in Table 1 (main paper). The means in Table 1 are geometric means estimated from analysis of population growth since 1963 in Minnesota and the early 1940s in Illinois and Wisconsin. The pre-Bt means used in the economic analysis are arithmetic means of observed densities for 1976 to 1995 , a more recent 20-yr period that better represents modern management practices and levels of maize hectares in the states' respective agricultural landscapes.

The annual average larval densities based on the statewide surveys were used for Illinois, Minnesota, and Wisconsin for 1996 to 2009 (fig. S1, Excel file). In Illinois, the traditional statewide survey was not conducted in 1997 and 1998. However, for 1997, larval data from several field research sites spread throughout Illinois $(\mathrm{N}=57)$, were available (S15), so the economic analysis used the average larval density of 1.13 for 1997 in Illinois. For 1998 in Illinois, the economic analysis used a larval density of 0.71 , which is the linear interpolation between the observations for 1997 and 1999. For Iowa and Nebraska, larval data were assembled from field research sites around each state. Again, larval data from several field research sites spread throughout Iowa $(\mathrm{N}=42)$ and Nebraska $(\mathrm{N}=63)$ were available for 1997 (S15). For Iowa, data from annual research trials conducted at one location were available for 1996 to 2009 (K. Pecinovsky), plus from field trials conducted at various locations around the state for 2000 to 
2002 (R. Hellmich). For Nebraska, data from research trials conducted at one location were available for 1997 to 2005 (T. Hunt). The spreadsheet created to document this analysis provides these larval data (see Documentation section). For each year, the average larval density across all observations was used as the state average larval density for the economic analysis. In years with no available data (Iowa 2009; Nebraska 1996, 2006-2009), given the similar-shaped decline in $O$. nubilalis moth flight data in Iowa and Nebraska as in Minnesota (all high Bt use states: fig. 2, main paper), the same annual proportional decline in larval densities from the long-term average was used for Iowa and Nebraska as observed in Minnesota. We viewed this as a reasonable approximation because both Iowa and Nebraska are two of the highest Bt use states (table S1). The spreadsheet created to document this analysis reports the larval data used for the economic analysis (see Documentation section).

\section{Annual direct benefits calculation for Bt growers}

Annual data for total maize planted, average yield, average price, and the proportion planted to $\mathrm{Bt}$ maize are available (tables S1, S5; S18-S19). The expected proportion of yield lost $(\mathrm{E}[\lambda])$ is calculated from the fall-collected $O$. nubilalis larval population density for each state $(n)$ and the average yield for Bt and non-Bt maize $\left(Y_{B t}\right.$ and $\left.Y_{n o n-B t}\right)$. The net benefit $(\$ / \mathrm{ha})$ for Bt growers is the Bt yield minus the non-Bt yield, this quantity multiplied by the maize price, and then the additional cost for Bt maize seed subtracted (table S5). Multiplying this net benefit by the total planted area (ha) gives the annual total net benefit (\$). Annual values are adjusted for inflation to a base year of 2009 using the Consumer Price Index (S25).

\section{Additional cost of Bt maize seed}

The additional cost for Bt maize seed (\$/ha), sometimes referred to as the "technology fee", is derived from an extensive data set on farmer purchases of maize seed from a U.S. Dept. Agric. funded research project (S26). The data were collected annually from 2000 to 2007 by dmrkynetec (www.dmrkynetec.com) via a telephone survey of a stratified sample of U.S. maize farmers. For the five states examined here, the data contain 95,685 observations of individual purchases of maize seed over the eight years from 9,864 different farms. The collected data allow calculation of the average cost each year for each type of seed purchased. The additional cost in any given year for the $\mathrm{Bt}$ trait registered for control of $O$. nubilalis is calculated relative to the average cost in the same year with only the $\mathrm{Bt}$ trait for $O$. nubilalis control removed. For singletraited maize seed, this is relative to the average cost for conventional (non-Bt) seed. For multiple-traited maize seed, this is relative to the average cost with only the Bt trait for $O$. nubilalis control removed. Thus, for example, the additional cost for Bt maize combined with herbicide tolerance is relative to the average cost for maize seed with only herbicide tolerance (not conventional maize). Table S5 reports the state average annual cost $(\$ / \mathrm{ha})$ for Bt maize with traits registered for control of $O$. nubilalis, with annual averages weighted by the planted area. A negative exponential function was fit to these data via least squares to project the cost for years without data (1996-1999, 2008-2009): $C=C_{1995}\left(1-\exp \left(-(\alpha / y)^{\theta}\right)\right)$, where $C$ is the average cost for Bt maize (\$/ha), $C_{1995}$ is the estimated cost in 1995, $y$ is the number of years since 1995, and $\alpha$ and $\theta$ are additional parameters to estimate (table S4). Multiplying these additional annual costs by the planted area and the percentage Bt maize reported (table S1) gives the additional annual cost for Bt maize relative to non-Bt maize. Adjusting these annual values for inflation to a base 
year of 2009 using the Consumer Price Index (S25) and summing across years gives a cumulative additional cost of $\$ 1.67$ billion assuming a discount rate of $0 \%$.

\section{Annual suppression benefits calculation for non-Bt growers}

The annual suppression benefit for non-Bt maize is calculated for 1996-2009 under the counterfactual assumption that $\mathrm{Bt}$ maize had never been commercialized and so the $O$. nubilalis population never suppressed. Annual state average yields for this counterfactual scenario are estimated based on annual larval densities for 1996-2009 and the imputed annual state average Bt maize yields. Larval densities for 1996-2009 for this counterfactual scenario are based on the long-term average larval densities for each state, but if the actual observed larval density exceeded this average, the higher observed value is used. This change was imposed in 1996 for Illinois (1.52), in 1997 for Minnesota (1.08), in Wisconsin for 1996 (0.64) and for 2002 (0.66), in Iowa for 1999 (2.09), for 2001 (1.59), for 2002 (1.90), and for 2005 (2.10), and in Nebraska for 1997 (1.85) and for 2001 (2.35), with the resulting larval population density reported in parentheses. The average proportion of yield lost $(\mathrm{E}[\lambda])$ is calculated based on this larval density for each year. Annual state average yields for this counterfactual scenario that $\mathrm{Bt}$ maize had not been commercialized $\left(Y_{\text {non-Bt }}\right)$ are calculated as $Y_{\text {no Bt }}=(1-E[\lambda]) Y_{B t}$ for each year, where the Bt yield each year is the same as used to calculate benefits for Bt growers (table S5). The yield gain for non-Bt growers due to the suppression of $O$. nubilalis is the non-Bt yield calculated for each state based on the actual observed state average larval density $\left(Y_{\text {non-Bt }}\right)$ minus the yield based on the larval density under the counterfactual case that Bt maize had never been commercialized $\left(Y_{\text {no } B t}\right)$. This gain multiplied by the maize price is the benefit ( $\$ / \mathrm{ha})$ for non-Bt growers due to O. nubilalis suppression. Multiplying this benefit by the total planted area (ha) gives the annual total net benefit (\$). Annual values are adjusted for inflation to a base year of 2009 using the Consumer Price Index (S25).

\section{Cumulative benefits}

Annual benefits are accumulated over years by first discounting them to equivalent 2009 values and then summing across years. Specifically, the accumulated total value of benefits is $V=\sum_{t=1996}^{2009} V_{t}(1+\delta)^{(2009-t)}$, where $\delta$ is the annual discount (interest) rate and $V_{t}$ is the value of the benefits $(\$)$ in year $t$. Results reported in the main text are with a $0 \%$ discount rate. With a $10 \%$ discount rate, the cumulative benefits for $\mathrm{Bt}$ and non-Bt maize are over $\$ 11.4$ billion, with non-Bt maize accounting for over $\$ 7.0$ billion of this total. Results with intermediate discount rates are fairly close to a linear approximation between these results and so are not reported.

\section{Documentation}

To document the methods and assumptions of this analysis, a spreadsheet has been created that contains the data and calculations used to derive reported values. Interested readers can download the spreadsheet (http://www.aae.wisc.edu/mitchell/) or contact the authors to receive a copy.

\section{Caveats}

This economic analysis does not account for a variety of effects. A more complete economic approach (beyond the scope of this paper) would use a partial equilibrium model to incorporate 
price effects resulting from supply and demand shifts and the associated producer and consumer welfare effects in the maize market and in connected input and output markets (S27-30). A variety of other costs and benefits are not incorporated, including regulatory and compliance costs, various non-monetary benefits to farmers including changes in income risk, and environmental and human health costs and benefits (S16, S31-32).

\section{Supporting References and Notes}

S1. Anon. Fall Surveys for European corn borers in Illinois, On-line: http://www.ipm.uiuc.edu/fieldcrops/insects/european_corn borer/fall survey.html (accessed 8-5-10)

S2. Hamilton, K. et al., Wisconsin Dept. of Agric., Trade \& Consumer Protection, Wisconsin Pest Bulletin, 53 (20), Nov., 2008, On-line: http://pestbulletin.wi.gov/pdf/11-21-08.pdf

S3. K. L. Steffey, M. E. Gray. Is the European corn borer an endangered species? The Bulletin. 24, On-line: http://www.ipm.uiuc.edu/bulletin/article.php?id=865 (2007).

S4. D. W. Bartels, et. al., J. Econ. Entomol. 90, 449 (1997).

S5. Anonymous. 2000. Issues pertaining to the Bt plant pesticides Risk and Benefit Assessments. US EPA FIFRA Scientific Advisory Panel. October 18-20, 2000.

S6. Fernandez-Cornejo, J. and W.D. McBride. 2002. Agricultural Economic Report No. AER810, 67 pp.

S7. C. D. Pilcher et al. 2002. Biotechnology and the European corn borer: Measuring historical farmer perceptions and adoption of transgenic Bt corn as a pest management strategy. J. Econ. Entomol. 95: 878-892.

S8. USDA-ERS, Economic Research Service. July 1, 2009. On-line: http://www.ers.usda.gov/data/BiotechCrops/ExtentofAdoptionTable1.htm (accessed 4-5-10).

S9. U.S. Dept. of Agriculture, National Agricultural Statistics Service (NASS), Quick Stats. 1995-2009. On-line: http://www.nass.usda.gov/Statistics_by_Subject/index.php (accessed 8-5-10).

S10. E. C. Burkness, et al., Crop Prot. 21, 157 (2002).

S11. T. Royama, Analytical population dynamics. Chapman \& Hall, London (1992).

S12. R. M. Sibley, D. Barker, M. C. Denham, J. Hone, Pagel M. Science 309: 607-610 (2005).

S13. K. P. Burnham, D. R. Anderson. Model selection and multimodel inference: a practical information-theoretic approach ( $2^{\text {nd }}$ edn.). Springer, New York. (2002). 
S14. S. Weisberg. Applied linear regression, (3 ${ }^{\text {rd }}$ edn.) Wiley, New York. (2005).

S15. P. D. Mitchell, T. M. Hurley, B. A. Babcock, R. L. Hellmich, J. Agr. Resource Econ. 27, 390 (2002).

S16. T. M. Hurley, P. D. Mitchell, M. E. Rice, Am. J. Agr. Econ. 86, 345 (2004).

S17. M. Evans, N. A. J. Hastings, B. Peacock, Statistical Distributions, $3^{\text {rd }}$ ed. (John Wiley and Sons, New York, 2000).

S18. U.S. Department of Agriculture, National Agricultural Statistics Service, Quick Stats Online http://www.nass.usda.gov/ (accessed 11-15-09).

S19. U.S. Department of Agriculture, National Agricultural Statistics Service, Crop ProductionAcreage Supplement (PCP-BB) (USDA-NASS, Washington DC). Online http://usda.mannlib.cornell.edu/MannUsda/viewDocumentInfo.do?documentID $=1000$ (accessed 9-20-09).

S20. D. D. Calvin, "Economic Benefits of Transgenic Corn Hybrids for European Corn Borer Management in the United States." Public Interest Document Supporting the Registration and Exemption from the Requirement of a Tolerance for the Plant Pesticide Bacillus thuringiensis subsp. kurstaki Insect Control Protein as Expressed in Corn, 1996.

S21. European Corn Borer. Department of Entomology, Iowa State University, Ames, IA. Online: http://www.ent.iastate.edu/pest/cornborer/ (accessed 9-20-09).

S22. Some Factors Influencing Populations of European Corn Borer [Pyrausta nubilalis (Hbn.)] in the North Central States. North Central Publication 87, University of Minnesota Agricultural Experiment Station, St. Paul, MN (October 1959).

S23. Populations of European Corn Borer, Ostrinia nubilalis (Hbn.) in Field Corn, Zea mays (L.). North Central Regional Publication 129, Research Bulletin 776, University of Missouri College of Agriculture, Columbia, MO, July 1961.

S24. European Corn Borer, Ostrinia nubilalis (Hbn.) Populations in Field Corn, Zea mays (L.) in the North Central United States. North Central Regional Publication 175, Research Bulletin 225, University of Nebraska College of Agriculture, Lincoln, NE, August 1967.

S25. U.S. Department of Labor, Bureau of Labor Statistics. Consumer Price Index History Table: CPI-U U.S. All Indexes and Annual Percent Changes From 1913 to Present, Online ftp://ftp.bls.gov/pub/special.requests/cpi/cpiai.txt (accessed 9-20-09).

S26. J.P. Chavas, G. Shi, and K. Steigert. Pricing and Strategy in the U.S. Genetically Modified Seed Industry. U.S. Department of Agriculture, Cooperative State Research, Education, and Extension Service, National Research Initiative Grant in the Agricultural Markets and 
Trade Program, Agreement No. 2008-35400-18686. Online Summary: http://cris.csrees.usda.gov/cgi-bin/starfinder/23122/crisassist.txt

S27. J.M. Alston, G.W. Norton, P.G. Pardey, Science under Scarcity: Principles and Practice of Agricultural Research Evaluation and Priority Setting (Cornell University Press, Ithaca, NY, 1995).

S28. A. Sobolevsky, G. Moschini, H. Lapan, Am. J. Agr. Econ. 87, 621 (2005).

S29. G. K. Price, W. Lin, J. B. Falck-Zepeda, J. Fernandez-Cornejo. Technical Bulletin TB1906. (U.S. Department of Agriculture, Economic Research Service, Washington DC, 2003). Online http://www.ers.usda.gov/Publications/TB1906/ (accessed 9-20-09).

S30. J. Huang, R. Hu, H. van Meijl, F. van Tongeren. J. Dev. Econ. 75, 27 (2004).

S31. G. Moschini, Eur. Rev. Agr. Econ. 35, 331 (2008).

S32. R. E. Just, J. M. Alston, D. Zilberman, Regulating Agricultural Biotechnology: Economics and Policy. (Springer, New York, 2006). 
table S1. Percentage of maize (dent corn) planted to corn hybrids expressing one or more toxins from lepidopteran-active Bacillus thuringiensis for management of $O$. nubilalis in Midwestern corn growing states.

\begin{tabular}{|c|c|c|c|c|c|c|c|c|c|c|c|c|c|c|c|}
\hline \multirow[b]{2}{*}{ Year } & \multicolumn{3}{|c|}{ Minnesota } & \multicolumn{3}{|c|}{ Illinois } & \multicolumn{3}{|c|}{ Wisconsin } & \multicolumn{3}{|c|}{ Iowa } & \multicolumn{3}{|c|}{ Nebraska } \\
\hline & $\% \mathrm{Bt}$ & $\begin{array}{l}\text { Cumul } \\
\text {-ative } \\
\text { mean } \\
\% \mathrm{Bt}^{\mathrm{a}}\end{array}$ & $\begin{array}{c}\text { Total } \\
\text { planted } \\
\text { ha } \\
\text { (mil.) }\end{array}$ & $\% \mathrm{Bt}$ & $\begin{array}{l}\text { Cumul } \\
\text {-ative } \\
\text { mean } \\
\% \mathrm{Bt}^{\mathrm{a}}\end{array}$ & $\begin{array}{c}\text { Total } \\
\text { planted } \\
\text { ha } \\
\text { (mil.) }\end{array}$ & $\% \mathrm{Bt}$ & $\begin{array}{l}\text { Cumul } \\
\text {-ative } \\
\text { mean } \\
\% \mathrm{Bt}^{\mathrm{a}}\end{array}$ & $\begin{array}{c}\text { Total } \\
\text { planted } \\
\text { ha } \\
\text { (mil.) }\end{array}$ & $\% \mathrm{Bt}$ & $\begin{array}{l}\text { Cumul } \\
\text {-ative } \\
\text { mean } \\
\% \mathrm{Bt}^{\mathrm{a}}\end{array}$ & $\begin{array}{c}\text { Total } \\
\text { planted } \\
\text { ha } \\
\text { (mil.) }\end{array}$ & $\% \mathrm{Bt}$ & $\begin{array}{l}\text { Cumul } \\
\text {-ative. } \\
\text { mean } \\
\% \mathrm{Bt}^{\mathrm{a}}\end{array}$ & $\begin{array}{c}\text { Total } \\
\text { planted } \\
\text { ha } \\
\text { (mil.) }\end{array}$ \\
\hline 1995 & 0.0 & 0.0 & 2.71 & 0.0 & 0.0 & 4.13 & 0.0 & 0.0 & 1.48 & 0.0 & 0.0 & 4.82 & 0.0 & 0.0 & 3.24 \\
\hline 1996 & 12.6 & 12.6 & 3.04 & 7.8 & 7.8 & 4.45 & 1.4 & 1.4 & 1.58 & 11.1 & 11.1 & 5.14 & 10.2 & 10.2 & 3.44 \\
\hline 1997 & 26.8 & 19.7 & 2.83 & 12.4 & 10.1 & 4.53 & 7.6 & 4.5 & 1.56 & 20.2 & 15.7 & 4.94 & 18.3 & 14.3 & 3.60 \\
\hline 1998 & 49.2 & 29.5 & 2.95 & 35.0 & 18.4 & 4.29 & 13.0 & 7.3 & 1.50 & 39.6 & 23.6 & 5.06 & 38.9 & 22.5 & 3.56 \\
\hline 1999 & 35.0 & 30.9 & 2.87 & 31.0 & 21.6 & 4.37 & 10.0 & 8.0 & 1.46 & 36.0 & 26.7 & 4.90 & 33.0 & 25.1 & 3.48 \\
\hline 2000 & 30.0 & 30.7 & 2.91 & 14.0 & 20.0 & 4.53 & 14.0 & 9.2 & 1.42 & 25.0 & 26.4 & 4.98 & 26.0 & 25.3 & 3.44 \\
\hline 2001 & 29.0 & 30.4 & 2.75 & 13.0 & 18.9 & 4.45 & 12.0 & 9.7 & 1.38 & 26.0 & 26.3 & 4.73 & 26.0 & 25.4 & 3.28 \\
\hline 2002 & 33.0 & 30.8 & 2.91 & 19.0 & 18.9 & 4.49 & 17.0 & 10.7 & 1.48 & 34.0 & 27.4 & 4.94 & 38.0 & 27.2 & 3.40 \\
\hline 2003 & 38.0 & 31.7 & 2.91 & 24.0 & 19.5 & 4.53 & 23.0 & 12.3 & 1.52 & 37.0 & 28.6 & 4.98 & 41.0 & 28.9 & 3.28 \\
\hline 2004 & 46.0 & 33.3 & 3.04 & 28.0 & 20.5 & 4.76 & 24.0 & 13.6 & 1.46 & 44.0 & 30.3 & 5.14 & 47.0 & 30.9 & 3.34 \\
\hline 2005 & 44.0 & 34.4 & 2.95 & 30.0 & 21.4 & 4.90 & 28.0 & 15.0 & 1.54 & 46.0 & 31.9 & 5.18 & 51.0 & 32.9 & 3.44 \\
\hline 2006 & 44.0 & 35.2 & 2.95 & 43.0 & 23.4 & 4.57 & 32.0 & 16.5 & 1.48 & 50.0 & 33.5 & 5.10 & 52.0 & 34.7 & 3.28 \\
\hline 2007 & 54.0 & 36.8 & 3.40 & 59.0 & 26.4 & 5.34 & 41.0 & 18.6 & 1.64 & 59.0 & 35.7 & 5.75 & 56.0 & 36.5 & 3.80 \\
\hline 2008 & 59.0 & 38.5 & 3.12 & 65.0 & 29.3 & 4.90 & 49.0 & 20.9 & 1.54 & 69.0 & 38.2 & 5.38 & 62.0 & 38.4 & 3.56 \\
\hline 2009 & 64.0 & 40.3 & 3.08 & 69.0 & 32.2 & 4.86 & 50.0 & 23.0 & 1.56 & 71.0 & 40.6 & 5.54 & 68.0 & 40.5 & 3.70 \\
\hline
\end{tabular}

${ }^{\mathrm{a}}$ Cumulative mean \% Bt values were calculated by summing the \% Bt over successive years and dividing by the number of years; e.g., for MN years 1996-1998: cumul. mean $\% \mathrm{Bt}=12.6+26.8+49.2=88 . ; 88.6 / 3=29.5 \%$; for $\mathrm{MN}, 1996-1999,12.6+26.8+49.2+35.0=123.6 ; 123.6 /$ $4=30.9 \%)$.

Data sources (S5-S9). 
table S2. Summary statistics for competing models of $O$. nubilalis population growth in relation to main effects and interactions among fall larval density and proportion of state maize crop planted in Bt hybrids, grouped by state. Models are ranked by descending relative weight (w) of support, based on $\triangle \mathrm{BIC}$.

\begin{tabular}{lcccccc}
\multicolumn{1}{c}{ Model $^{\mathrm{a}}$} & SE resid & $\mathrm{df}^{\mathrm{b}}$ & $R^{2} \mathrm{adj}$ & $\mathrm{BIC}^{\mathrm{c}}$ & $\Delta \mathrm{BIC}^{\mathrm{d}}$ & $w_{\mathrm{i}}^{\mathrm{e}}$ \\
\hline$S+D+P B t$ & 0.722 & 4,172 & 0.380 & 413.1 & 0.00 & 0.82 \\
$S+D+P B t+D^{*} P B t$ & 0.721 & 5,171 & 0.382 & 416.6 & 3.47 & 0.14 \\
$S+D+P B t+S^{*} P B t$ & 0.720 & 6,170 & 0.383 & 420.4 & 7.28 & 0.02 \\
$S+D+P B t+S^{*} D$ & 0.724 & 6,170 & 0.377 & 422.2 & 9.04 & 0.01 \\
$S+D+P B t+S^{*} P B t+D^{*} P B t$ & 0.718 & 7,169 & 0.387 & 423.5 & 10.34 & 0.00 \\
$D+P B t$ & 0.762 & 2,174 & 0.309 & 423.9 & 10.81 & 0.00 \\
$S+D+P B t+D^{*} P B t+S^{*} D$ & 0.724 & 7,169 & 0.376 & 426.5 & 13.39 & 0.00 \\
$D+P B t+D^{*} P B t$ & 0.764 & 3,173 & 0.307 & 428.7 & 15.52 & 0.00 \\
$S+D+P B t+S^{*} D+S^{*} P B t$ & 0.721 & 8,168 & 0.383 & 428.8 & 15.66 & 0.00 \\
$S+D+P B t+S^{*} D+S^{*} P B t+D^{*} P B t$ & 0.720 & 9,167 & 0.384 & 432.6 & 19.47 & 0.00 \\
$S+D+P B t+S^{*} D+D^{*} P B t+S^{*} P B t+S^{*} D^{*} P B t$ & 0.718 & 11,165 & 0.387 & 439.9 & 26.73 & 0.00 \\
$S+D$ & 0.791 & 3,173 & 0.256 & 441.2 & 28.06 & 0.00 \\
$D$ & 0.814 & 1,175 & 0.212 & 443.0 & 29.83 & 0.00 \\
$S+D+S^{*} D$ & 0.789 & 5,171 & 0.261 & 448.4 & 35.26 & 0.00 \\
$P B t$ & 0.910 & 1,175 & 0.017 & 482.3 & 69.12 & 0.00 \\
$S$ & 0.922 & 2,174 & -0.011 & 491.4 & 78.23 & 0.00 \\
$S+P B t$ & 0.915 & 3,173 & 0.006 & 492.5 & 79.39 & 0.00 \\
$S+P B t+S^{*} P B t$ & 0.918 & 5,171 & -0.001 & 502.1 & 88.93 & 0.00 \\
\hline
\end{tabular}

${ }^{a}$ Dependent variable was population growth, $r_{t}=\ln \left(N_{t} / N_{t-1}\right), N_{t}=$ state-wide mean no. larvae per 100 plants in non-Bt fields in fall of year $t$. Independent variables were $D=\ln \left(N_{t-1}\right), P B t=$ proportion of state's total crop in $B t$ maize, and $S=$ indicator variable for state (IL, MN or WI).

${ }^{\mathrm{b}}$ No. model parameters -1, and residual degrees of freedom. There were 64 cases in 1944-2009 from IL, 46 in 1963-2009 from MN, and 67 in 19432009 from WI, for a total of 177 cases.

${ }^{\mathrm{c}}$ Bayesian information criterion (see S13).

${ }^{\mathrm{d}}$ Change in BIC relative to smallest BIC (see S13).

${ }^{\mathrm{e}}$ Relative weight of support (see S13). 
table S3. Regression statistics and estimated mean densities of larvae per 100 plants in Bt- and non-Bt fields (landscape level means) before and after adoption of $\mathrm{Bt}$ maize in three Midwestern states.

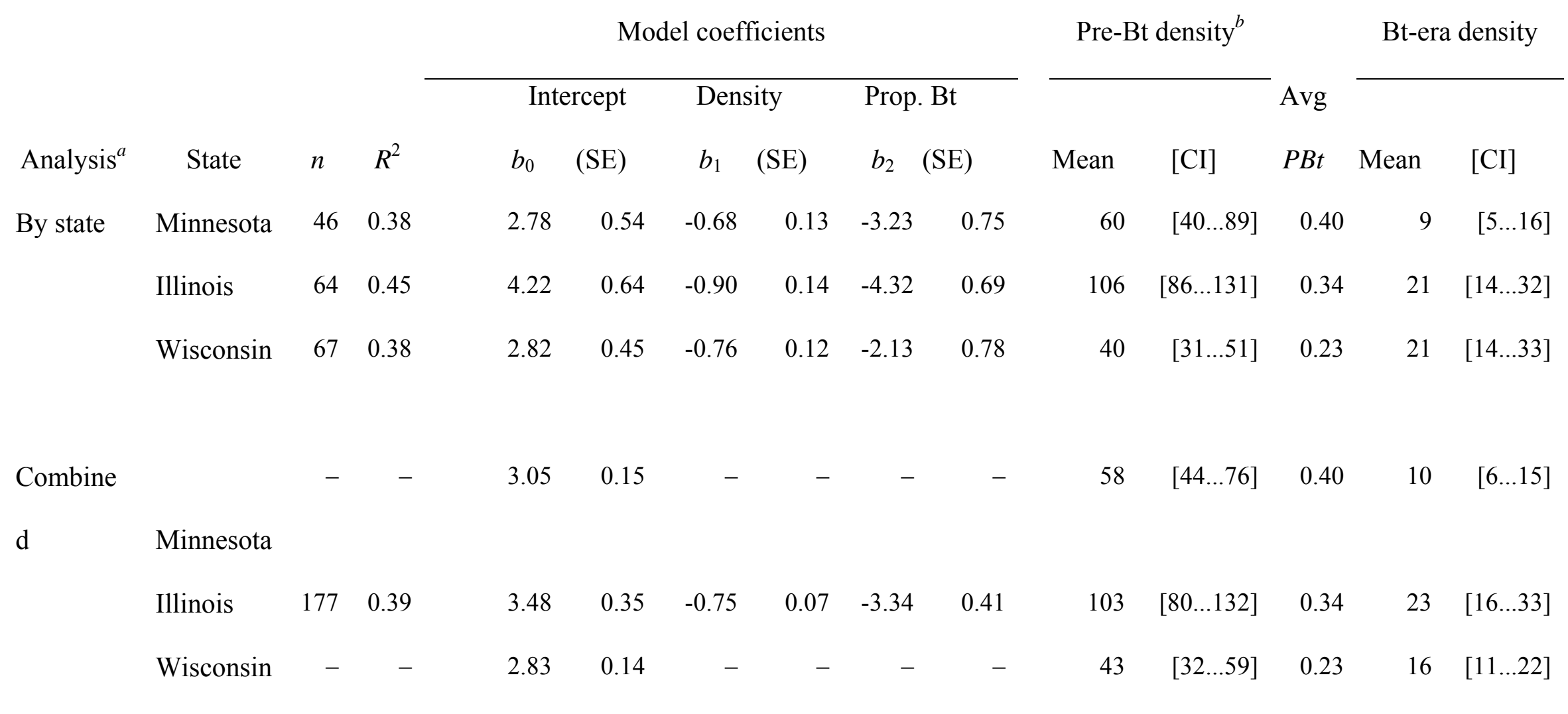

${ }^{a}$ Regression model for per-capita growth rate, $r=\ln \left(N_{t-1} / N_{t}\right)$, with coefficients of $b_{0}$ for intercept, $b_{1}$ for regressor $D=\ln \left(N_{t-1}\right)$, and $b_{2}$ for regressor $P B t=$ proportion crop in Bt-maize. Model fit to data from individual states separately, $r=b_{0}+b_{1} D+b_{2} P B t$, or to the three states combined, but with differences among states $(S)$ reflected by state-specific intercepts. 
${ }^{b}$ Mean densities of larvae were estimated by setting $r=0$ and solving for $N^{*}=\exp \left(-\left(b_{0}+b_{2} P B t\right) / b_{1}\right)$ (see Fig. S2). Mean for pre-Bt era used $P B t=0$; Bt era used 14-year average PBt. Confidence intervals (95\% CIs) were estimated with the delta method (S14) in log scale and then back-transformed to arithmetic scale. 

table S4. Annual state average maize yields and prices and the extra cost (“technology fee") for Bt maize seed used for economic analysis.

\begin{tabular}{|c|c|c|c|c|c|c|c|c|c|c|c|c|c|c|c|}
\hline \multirow[b]{2}{*}{ Year } & \multicolumn{3}{|c|}{------ Minnesota ------ } & \multicolumn{3}{|c|}{------ Illinois ------ } & \multicolumn{3}{|c|}{------ Wisconsin ------ } & \multicolumn{3}{|c|}{------ Iowa ------ } & \multicolumn{3}{|c|}{------ Nebraska ------ } \\
\hline & $\begin{array}{c}\text { Yield }^{\mathrm{a}} \\
(\mathrm{Mg} / \mathrm{ha})\end{array}$ & $\begin{array}{l}\text { Price }^{\mathrm{a}} \\
(\$ / \mathrm{Mg})\end{array}$ & $\begin{array}{l}\text { Cost } \\
(\$ / \mathrm{ha})\end{array}$ & $\begin{array}{c}\text { Yield }^{\mathrm{a}} \\
(\mathrm{Mg} / \mathrm{ha})\end{array}$ & $\begin{array}{l}\text { Price }^{a} \\
(\$ / \mathrm{Mg})\end{array}$ & $\begin{array}{l}\text { Cost } \\
(\$ / h a)\end{array}$ & $\begin{array}{c}\text { Yield }^{\mathrm{a}} \\
(\mathrm{Mg} / \mathrm{ha})\end{array}$ & $\begin{array}{l}\text { Price }^{\mathrm{a}} \\
(\$ / \mathrm{Mg})\end{array}$ & $\begin{array}{l}\text { Cost } \\
(\$ / h a)\end{array}$ & $\begin{array}{c}\text { Yield }^{\mathrm{a}} \\
(\mathrm{Mg} / \mathrm{ha})\end{array}$ & $\begin{array}{l}\text { Price }^{\mathrm{a}} \\
(\$ / \mathrm{Mg})\end{array}$ & $\begin{array}{l}\text { Cost } \\
(\$ / h a)\end{array}$ & $\begin{array}{c}\text { Yield }^{\mathrm{a}} \\
\text { (Mg/ha) }\end{array}$ & $\begin{array}{l}\text { Price }^{\mathrm{a}} \\
(\$ / \mathrm{Mg})\end{array}$ & $\begin{array}{l}\text { Cost } \\
(\$ / h a)\end{array}$ \\
\hline 1995 & 7.47 & 123.64 & -- & 7.09 & 129.94 & -- & 7.15 & 122.46 & - & 7.72 & 126.00 & -- & 6.97 & 126.79 & -- \\
\hline 1996 & 7.84 & 97.26 & $20.46^{\mathrm{c}}$ & 8.53 & 109.86 & $20.93^{c}$ & 6.97 & 103.16 & $17.49^{\mathrm{c}}$ & 8.66 & 102.38 & $20.74^{\mathrm{c}}$ & 8.97 & 103.95 & $22.24^{\mathrm{c}}$ \\
\hline 1997 & 8.28 & 84.66 & $20.41^{\mathrm{c}}$ & 8.10 & 99.62 & $20.93^{c}$ & 8.28 & 92.14 & $17.49^{\mathrm{c}}$ & 8.66 & 91.74 & $20.74^{\mathrm{c}}$ & 8.28 & 91.35 & $22.24^{\mathrm{c}}$ \\
\hline 1998 & 9.60 & 67.33 & $20.08^{\mathrm{c}}$ & 8.85 & 80.33 & $20.93^{c}$ & 8.60 & 72.45 & $17.49^{\mathrm{c}}$ & 9.10 & 73.24 & $20.74^{c}$ & 9.10 & 74.03 & $22.19^{c}$ \\
\hline 1999 & 9.41 & 63.00 & $19.44^{\mathrm{c}}$ & 8.79 & 75.21 & $20.93^{c}$ & 8.97 & 69.69 & $17.49^{\mathrm{c}}$ & 9.35 & 67.73 & $20.74^{\mathrm{c}}$ & 8.72 & 68.91 & $21.88^{\mathrm{c}}$ \\
\hline 2000 & 9.10 & & $19.39^{b}$ & 9.48 & & $18.65^{\mathrm{b}}$ & 8.28 & & $16.01^{\mathrm{b}}$ & 9.04 & 1 & $20.28^{\mathrm{b}}$ & 7.91 & 81 & $21.34^{b}$ \\
\hline 2001 & 8.16 & 74.81 & $15.84^{\mathrm{b}}$ & 9.54 & 80.33 & $20.60^{\mathrm{b}}$ & 7.97 & 77.57 & $15.56^{\mathrm{b}}$ & 9.16 & 74.81 & $20.24^{\mathrm{b}}$ & 9.23 & 76.39 & $22.06^{b}$ \\
\hline 2002 & 9.85 & 84.66 & $17.42^{\mathrm{b}}$ & 8.47 & 92.53 & $22.09^{b}$ & 8.47 & 87.41 & $16.11^{\mathrm{b}}$ & 10.23 & 87.41 & $20.82^{\mathrm{b}}$ & 8.03 & 91.35 & $18.17^{b}$ \\
\hline 2003 & 9.16 & 92.53 & $16.51^{b}$ & 10.29 & 95.29 & $22.20^{\mathrm{b}}$ & 8.10 & 92.53 & $19.89^{\mathrm{b}}$ & 9.85 & 93.32 & $20.73^{b}$ & 9.16 & 94.11 & $15.63^{b}$ \\
\hline 2004 & 9.98 & 76.39 & $15.27^{\mathrm{b}}$ & 11.30 & 84.26 & $20.00^{\mathrm{b}}$ & 8.53 & 84.66 & $20.68^{b}$ & 11.36 & 78.36 & $22.53^{b}$ & 10.42 & 79.54 & $19.18^{b}$ \\
\hline 2005 & 10.92 & 73.24 & $12.46^{\mathrm{b}}$ & 8.97 & 81.90 & $12.49^{\mathrm{b}}$ & 9.29 & 76.39 & $15.99^{b}$ & 10.86 & 76.39 & $15.02^{b}$ & 9.66 & 75.60 & $12.56^{\mathrm{b}}$ \\
\hline 2006 & 10.10 & 113.79 & $16.68^{\mathrm{b}}$ & 10.23 & 120.88 & $14.91^{\mathrm{b}}$ & 8.97 & 119.70 & $16.00^{\mathrm{b}}$ & 10.42 & 119.31 & $18.19^{\mathrm{b}}$ & 9.54 & 118.13 & $13.72^{b}$ \\
\hline 2007 & 9.16 & 162.62 & $11.20^{\mathrm{b}}$ & 10.98 & 161.04 & $9.64^{b}$ & 8.47 & 161.83 & $13.76^{\mathrm{b}}$ & 10.73 & 168.92 & $13.91^{\mathrm{b}}$ & 10.04 & 163.01 & $15.11^{b}$ \\
\hline 2008 & 10.29 & 154.35 & $12.32^{\mathrm{c}}$ & 11.23 & 157.89 & $7.53^{c}$ & 8.60 & 153.17 & $11.41^{\mathrm{c}}$ & 10.73 & 161.44 & $12.01^{\mathrm{c}}$ & 10.23 & 159.47 & $12.35^{\mathrm{c}}$ \\
\hline 2009 & 10.92 & 145.69 & $11.77^{\mathrm{c}}$ & 10.92 & 143.72 & $5.74^{\mathrm{c}}$ & 9.60 & 145.69 & $9.18^{c}$ & 11.42 & 147.66 & $10.07^{\mathrm{c}}$ & 11.17 & 145.69 & $11.54^{\mathrm{c}}$ \\
\hline
\end{tabular}

${ }^{a}$ State average maize yield $(\mathrm{Mg})$ per harvested hectare and state average farmer price $(\$ / \mathrm{Mg})$ for maize $(\mathrm{S} 18)$.

${ }^{\mathrm{b}}$ Planted-area weighted average calculated from annual telephone survey of farmers (S26).

${ }^{\mathrm{c}}$ Calculated using $C=C_{1995}\left(1-\exp \left(-(\alpha / y)^{\theta}\right)\right)$, where $y$ is the number of years since 1995 and the parameters $C_{1995}, \alpha$ and $\theta$ are estimated via a non-linear least squares fit to the survey averages (S8). IL: $C=20.927 \exp \left[-(10.838 / y)^{4.443}\right]\left(\mathrm{R}^{2}=0.821\right)$; IA: $C=$ $20.742 \exp \left[-(12.482 / y)^{3.557}\right]\left(\mathrm{R}^{2}=0.653\right) ; \mathrm{MN}: C=20.458 \exp \left[-(11.985 / y)^{1.000}\right]\left(\mathrm{R}^{2}=0.576\right) ; \mathrm{NE}: C=22.239 \exp \left[-(11.166 / y)^{1.383}\right]\left(\mathrm{R}^{2}\right.$ $=0.685)$; WI: $C=17.494 \exp \left[-(13.152 / y)^{4.722}\right]\left(\mathrm{R}^{2}=0.334\right)$. Note that estimation imposed $\theta=1.000$ for $\mathrm{MN}$ and $C_{1995}=22.239$ for $\mathrm{NE}$ to improve the performance of the predicted cost in years without data. 
table S5. Imputed annual state average harvested yields $(\mathrm{Mg} / \mathrm{ha})$ for $\mathrm{Bt}$ maize $(\mathrm{Bt})$ and non-Bt maize (non-Bt) hectares and for all planted hectares if $\mathrm{Bt}$ had not been commercialized (No Bt).

\begin{tabular}{|c|c|c|c|c|c|c|c|c|c|c|c|c|c|c|c|}
\hline \multirow[b]{3}{*}{ Year } & \multicolumn{3}{|c|}{------ Minnesota ------ } & \multicolumn{3}{|c|}{------ Illinois ------- } & \multicolumn{3}{|c|}{------ Wisconsin ------ } & \multicolumn{3}{|c|}{------ Iowa ------ } & \multicolumn{3}{|c|}{------ Nebraska ------ } \\
\hline & \multirow{2}{*}{\multicolumn{3}{|c|}{ non- }} & \multicolumn{3}{|c|}{ non- } & \multicolumn{3}{|c|}{ non- } & \multicolumn{3}{|c|}{ non- } & \multicolumn{3}{|c|}{ non- } \\
\hline & $\mathrm{Bt}$ & & No Bt & $\mathrm{Bt}$ & $\mathrm{Bt}$ & No Bt & $\mathrm{Bt}$ & $\mathrm{Bt}$ & No Bt & $\mathrm{Bt}$ & $\mathrm{Bt}$ & No Bt & $\mathrm{Bt}$ & $\mathrm{Bt}$ & No Bt \\
\hline 1995 & 8.43 & 7.47 & 7.47 & 7.65 & 7.09 & 7.09 & 7.83 & 7.15 & 7.15 & 8.36 & 7.72 & 7.72 & 7.60 & 6.97 & 6.97 \\
\hline 1996 & 8.31 & 7.78 & 7.77 & 9.17 & 8.48 & 8.48 & 7.35 & 6.96 & 6.96 & 9.23 & 8.59 & 8.52 & 9.69 & 8.89 & 8.88 \\
\hline 1997 & 8.71 & 8.13 & 8.13 & 8.61 & 8.02 & 7.98 & 8.54 & 8.26 & 8.09 & 9.19 & 8.53 & 8.48 & 8.90 & 8.15 & 8.15 \\
\hline 1998 & 9.75 & 9.46 & 9.12 & 9.18 & 8.67 & 8.51 & 8.71 & 8.58 & 8.25 & 9.36 & 8.93 & 8.64 & 9.38 & 8.92 & 8.60 \\
\hline 1999 & 9.62 & 9.30 & 9.00 & 9.01 & 8.68 & 8.36 & 9.29 & 8.94 & 8.80 & 9.91 & 9.03 & 9.03 & 9.10 & 8.54 & 8.34 \\
\hline 2000 & 9.34 & 9.00 & 8.74 & 9.81 & 9.42 & 9.09 & 8.53 & 8.24 & 8.08 & 9.50 & 8.88 & 8.77 & 8.21 & 7.80 & 7.53 \\
\hline 2001 & 8.41 & 8.06 & 7.86 & 10.08 & 9.46 & 9.35 & 8.28 & 7.93 & 7.85 & 9.73 & 8.96 & 8.96 & 9.91 & 8.98 & 8.98 \\
\hline 2002 & 10.15 & 9.71 & 9.49 & 8.93 & 8.36 & 8.28 & 8.87 & 8.39 & 8.39 & 10.84 & 9.91 & 9.91 & 8.46 & 7.77 & 7.76 \\
\hline 2003 & 9.31 & 9.07 & 8.71 & 10.69 & 10.17 & 9.90 & 8.34 & 8.02 & 7.90 & 10.30 & 9.59 & 9.51 & 9.53 & 8.91 & 8.74 \\
\hline 2004 & 10.08 & 9.89 & 9.43 & 11.52 & 11.21 & 10.68 & 8.67 & 8.49 & 8.22 & 11.64 & 11.14 & 10.74 & 10.50 & 10.35 & 9.62 \\
\hline 2005 & 11.06 & 10.81 & 10.34 & 9.23 & 8.86 & 8.56 & 9.58 & 9.17 & 9.08 & 11.40 & 10.39 & 10.39 & 9.83 & 9.49 & 9.01 \\
\hline 2006 & 10.22 & 10.01 & 9.56 & 10.46 & 10.05 & 9.70 & 9.20 & 8.87 & 8.72 & 10.62 & 10.22 & 9.80 & 9.67 & 9.40 & 8.86 \\
\hline 2007 & 9.23 & 9.08 & 8.63 & 11.09 & 10.82 & 10.28 & 8.67 & 8.34 & 8.21 & 10.83 & 10.59 & 10.00 & 10.14 & 9.92 & 9.29 \\
\hline 2008 & 10.37 & 10.18 & 9.70 & 11.32 & 11.08 & 10.49 & 8.69 & 8.51 & 8.23 & 10.81 & 10.56 & 9.98 & 10.33 & 10.06 & 9.47 \\
\hline 2009 & 11.01 & 10.76 & 10.30 & 10.93 & 10.89 & 10.13 & 9.68 & 9.52 & 9.17 & 11.51 & 11.19 & 10.63 & 11.28 & 10.93 & 10.34 \\
\hline
\end{tabular}




\section{Supplemental Figures}

figure S1.

A) Rosemount, MN

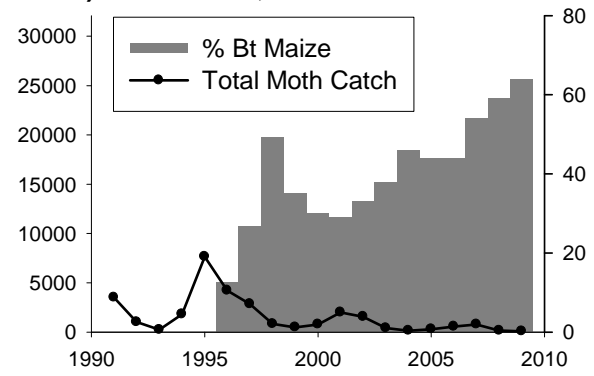

C) LeSueur, MN

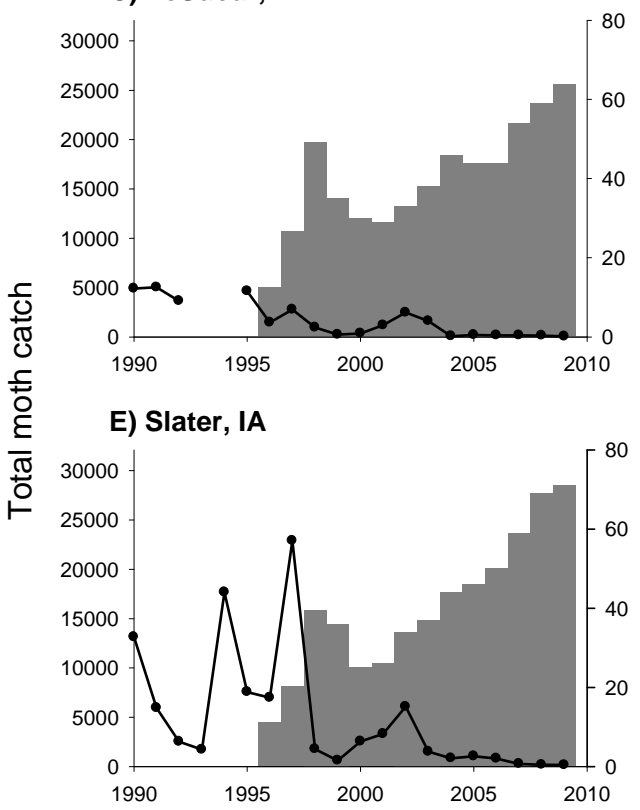

G) Concord, NE

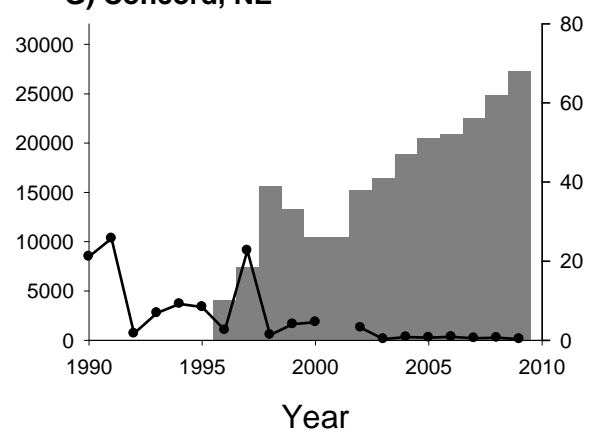

B) Blue Earth, MN

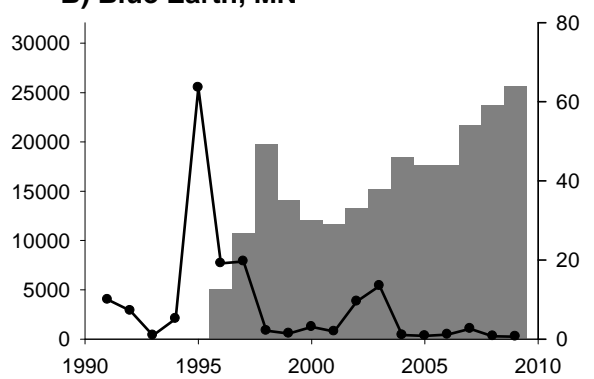

D) Ames, IA

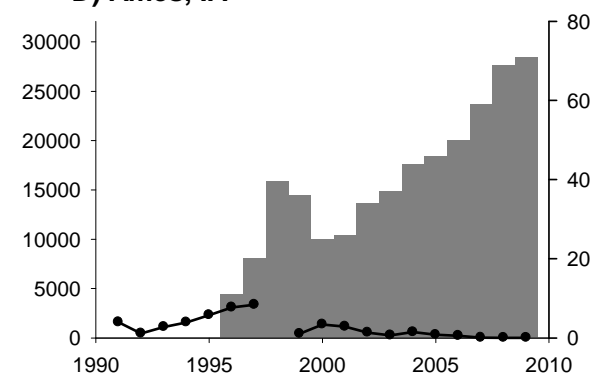

F) Clay Center, NE

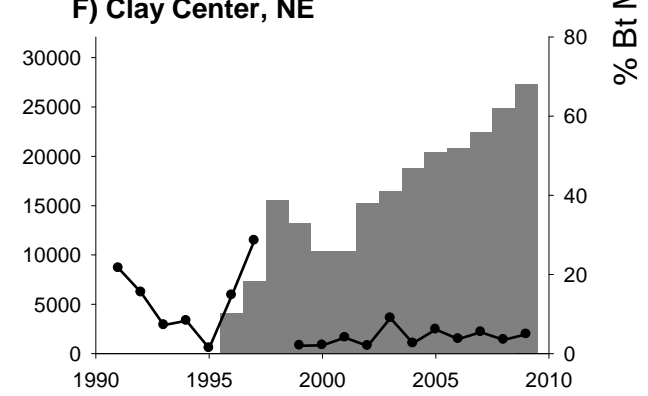

H) Rochelle, IL

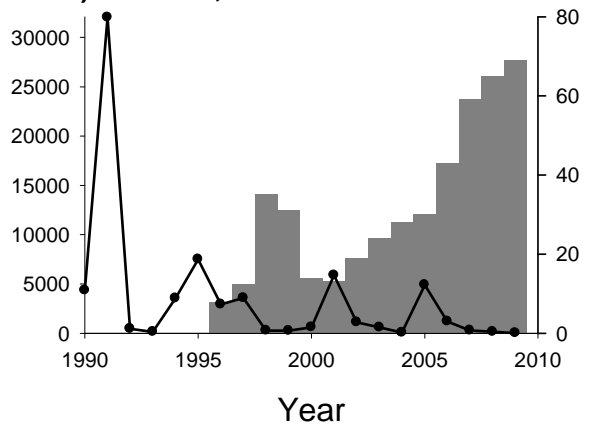

fig. S1. State average for percentage Bt maize and observed total annual light trap catch of adult male and female $O$. nubilalis for three locations in Minnesota (A-C), two locations in Iowa (DE), two locations in Nebraska $(F-G)$, and one location in Illinois $(\mathrm{H})$. 



\section{figure S2.}
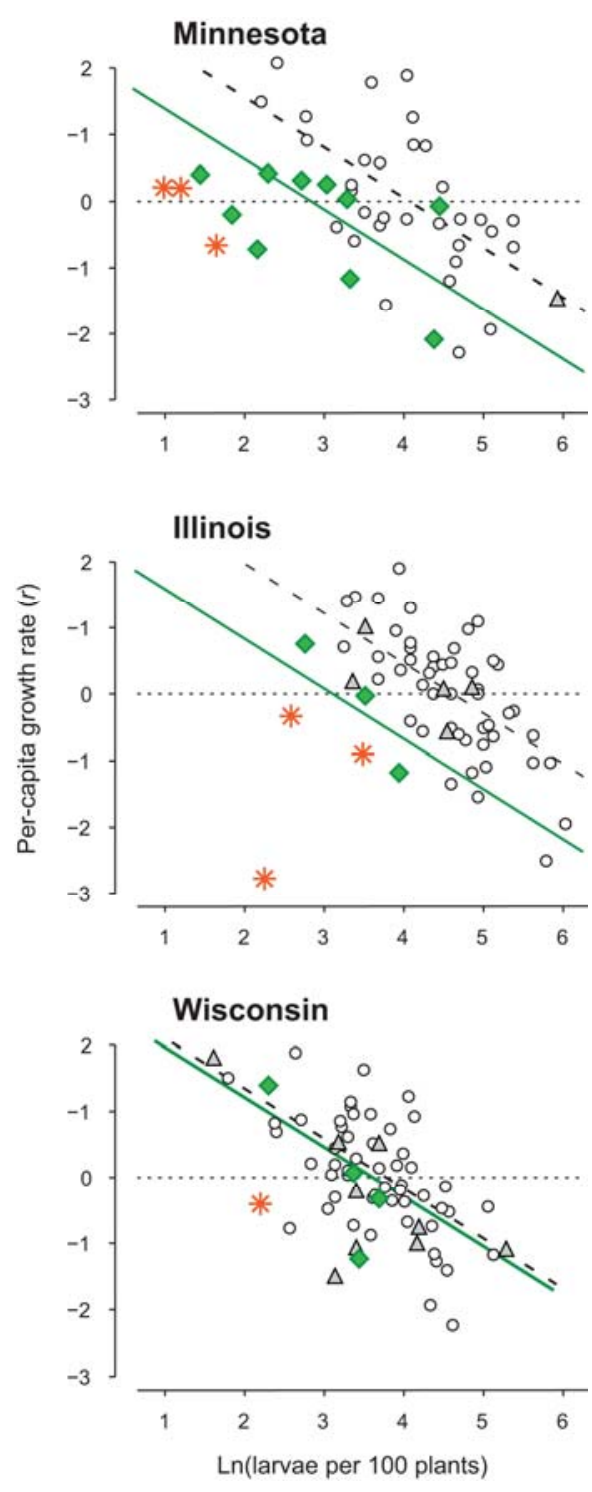

fig. S2. Effects of Bt-maize adoption and fall larval density on annual per-capita growth rates of O. nubilalis populations in non-Bt and Bt maize fields (landscape means) combined in three U.S. states. Symbols indicate level of Bt-maize adoption: open circles, pre-Bt years; gray triangles, $1-25 \%$; green diamonds, 26-50\%; orange asterisks, $>51 \%$. Bold dashed black line is least squares fit for main effects model, states combined, with $P B t=0$; green line is same with $P B t$ equal to respective state-wide 14-yr average (Table 1). Intersection between dotted line at $r=0$ and bold dashed line indicates mean larval density before adoption of Bt-maize, and intersection with green line shows extent to which mean density declined with adoption of Bt maize in each state (Table 1). Conclusions were equivalent to findings with refuge means from non-Bt field only (Fig. 3), but pre-Bt and Bt-era mean densities were lower. 